\title{
Peak residential electricity demand and social practices: deriving flexibility and greenhouse gas intensities from time use and locational data
}

Article

Accepted Version

Torriti, J., Hanna, R., Anderson, B., Yeboah, G. and Druckman, A. (2015) Peak residential electricity demand and social practices: deriving flexibility and greenhouse gas intensities from time use and locational data. Indoor and Built Environment, 24 (7). pp. 891-912. ISSN 1420-326X doi: https://doi.org/10.1177/1420326X15600776 Available at https://centaur.reading.ac.uk/40666/

It is advisable to refer to the publisher's version if you intend to cite from the work. See Guidance on citing.

To link to this article DOI: http://dx.doi.org/10.1177/1420326X15600776

Publisher: SAGE Publications

All outputs in CentAUR are protected by Intellectual Property Rights law, including copyright law. Copyright and IPR is retained by the creators or other copyright holders. Terms and conditions for use of this material are defined in the End User Agreement. 


\section{www.reading.ac.uk/centaur}

\section{CentAUR}

Central Archive at the University of Reading

Reading's research outputs online 


\title{
Peak residential electricity demand and social practices: Deriving flexibility and greenhouse gas intensities from time use and locational data
}

Jacopo Torriti (School of Construction Management and Engineering, University of Reading, Whiteknights, PO Box 219, Reading RG6 6AW, United Kingdom. Tel: +44 (0)118 378 8196; Email: j.torriti@reading.ac.uk)

Richard Hanna (School of Construction Management and Engineering, University of Reading) Ben Anderson (Sustainable Energy Research Group, Energy and Climate Change Division, University of Southampton)

Godwin Yeboah (Centre for Transport Research, School of Geosciences, University of Aberdeen) Angela Druckman (Centre for Environmental Strategy, University of Surrey)

\begin{abstract}
Peak residential electricity demand takes place when people conduct simultaneous activities at specific times of the day. Social practices generate patterns of demand and can help understand why, where, with whom and when energy services are used at peak time. The aim of this work is to make use of recent UK time use and locational data to better understand: (i) how a set of component indices on synchronisation, variation, sharing and mobility indicate flexibility to shift demand; and (ii) the links between people's activities and peaks in greenhouse gases' intensities. The analysis is based on a recent UK time use dataset, providing 1 minute interval data from GPS devices and 10 minute data from diaries and questionnaires for 175 data days comprising 153 respondents. Findings show how greenhouse gases' intensities and flexibility to shift activities vary throughout the day. Morning peaks are characterised by high levels of synchronisation, shared activities and occupancy, with low variation of activities. Evening peaks feature low synchronisation, and high spatial mobility variation of activities. From a network operator perspective, the results indicate that periods with lower flexibility may be prone to more significant local network loads due to the synchronization of electricity-demanding activities.
\end{abstract}

\section{Keywords}


Demand Side Response; Load shifting; Peak demand; Residential electricity demand; Time-use 


\section{Introduction}

The timing of electricity demand has significant implications for system balancing, utilities' pricing and future grid development. Understanding when energy demand occurs (i.e. at what time of the day) is inextricably related to questions of where energy demand takes place (i.e. in the home, at work and on the move) and why (i.e. what activities underpin it). Issues of time and timing have not featured strongly in energy research and energy policy analysis, as both have predominantly focused on estimating and reducing average total annual demand per capita, both at the individual household and system levels ${ }^{1}$. Traditionally, balancing demand and supply occurred via expansion of the capacity to deal with aggregate increases in electricity demand. More recently, greater awareness of the greenhouse gas (GHG) emissions from fossil fuel generation implies that concerns over demand-supply matching cannot justify grid expansion ${ }^{2}$. As a result, balancing electricity supply and demand is becoming an increasingly complex challenge, especially if countries cannot afford reserve capacity margins of $20 \%$, as in the past, to deal with peaks in demand $^{3}$. Policy solutions to this problem involve building new low-carbon capacity, increasing interconnections with other countries, developing energy storage technologies, and demand side response. The latter consists of price and time-based interventions aimed at shifting the timing of electricity demand. One of the main reasons why demand side response, at least in most European countries, has been relatively slow to emerge in the residential sector is due to the fact that evidence on the timing of electricity demand and how it varies in relation to people's practices is largely missing ${ }^{4}$. Smart meters are widely expected to fill this knowledge gap, but they will only provide information on how much electricity is consumed in every home, rather than disclose why electricity is used and thus which, if any, practices could be shifted across the day. If demand side response is to provide innovative ways of balancing supply and demand, any intervention on load shifting needs to be informed not only by load profiles, but also by what level of flexibility can be inferred from patterns of practices. This calls for detailed knowledge of when and where people engage in the same activities at the same time, which practices are shared with others, how much variation there is in activities throughout the day, and what the carbon intensities for such activities are. This study draws upon social practice theory, where there has been a paradigm shift in the units of analysis of peak electricity demand, from individual behaviour to the everyday practices performed and shared by people. While definitions of social practice theories are diverse ${ }^{5,6}$, practices can be understood as routines that are shared widely 
across different individuals. According to social practice theory, the timing of energy demand does not depend on individuals' decisions, but on activities and doings which are shared by people. ${ }^{6}$

This paper investigates how social practices, thus defined, generate patterns of demand at peak time, focusing on the implications for why, where and when energy services are used, rather than on how much electricity is consumed throughout the day. The paper examines how combinations of practices make up morning and evening peaks, and presents a set of component indices on synchronisation, variation, sharing and mobility (defined below in Table 2). These component indices feed into a flexibility index, which provides an indication of the potential to shift demand. The paper also links peaks in activities with peaks in GHG intensities. Several issues addressed here relate to system and policy-level empirical concerns around flexibility in demand and around the challenge of shifting peaks in electricity demand.

The starting point of this work is that the timing of social practices can play a vital role in describing the timing of electricity demand. In essence, whilst we recognise the importance of techno-economic approaches (e.g. the role of the price of electricity or the fabric of the building envelope), the timing of electricity demand is likely to depend on social obligations and societal constraints (such as dropping the children off at school or going to work). For this reason, the analysis is restricted to working age respondents as a way to focus on the relationship between social practices (often mediated by working patterns) and peak electricity demand.

Investigating the relationship between the timing of residential electricity demand and social practices in the household calls for an analytical framework addressing both theoretical and empirical issues. At a theoretical level, we will evaluate the extent to which concepts of time hotspots can facilitate an understanding of peak electricity demand in everyday life. This will inform the wider debate on the role of social practices in explaining the timing of energy services in particular and consumption more generally ${ }^{6}$. At an empirical level, the analysis of activities at times of peak demand will provide innovative methodological ways to study social practices based on secondary analysis of time use datasets. This approach involves understanding the extent to which socio-demographic variables can explain social practice ordering (i.e. variations in sequences of activities). As a methodological contribution, the paper develops methods of indirectly capturing the relationship between mobility and energy demand, hence linking the two 
normally separate domains of energy and transport studies. This will be done through the use of a flexibility index which relies on component indices, including synchronisation, shared activities, variation of activities, active home occupancy and spatial mobility.

The paper reviews the issue of peak electricity demand in the social sciences; provides an account of data and methods; presents findings on component indices as well as on the flexibility index and GHG intensities; and concludes with limitations and policy implications of this study.

\section{Peak electricity demand and the social sciences}

The body of research in the social sciences which focuses on people and peak electricity demand spreads across different disciplines. Depending on different theoretical assumptions, the relationship between peak electricity demand and people varies in social theory. Broadly speaking, people's actions are seen as either causing, or resulting in, peak electricity demand.

The 'cause' approaches, labelled by Shove' as the ABC model, where A stands attitude, B for behaviour and $\mathrm{C}$ for individual choice, see behaviour as a key element of why and when individuals occupy buildings and conduct activities leading to peak electricity demand. According to this view, peak electricity consumption is mainly caused by individuals' behaviour and, to a lesser extent, by social, cultural and entirely exogenous factors. The timing of electricity demand, from this perspective, would depend on individuals' predisposition to consumption ${ }^{8}$. Changes to the timing of electricity consumption could be triggered either by contextual factors such as price, direct feedback, limits to electricity supply, and weather conditions, or by attitudes towards proactive energy saving behaviour, on the one hand, and inertia driven by comfort and health concerns, on the other hand ${ }^{9}$. According to this view, behaviour consists of patterns in time, and investigations of behaviour deal with sequences that can be measured against time ${ }^{10}$.

An alternative approach emphasises the central role of human activities and social practices in shaping how and when peak electricity demand occurs. Social practices emphasise the importance of people's doings in relation to the timing of energy demand. For instance, picking up children from school may have a higher influence on peak energy demand than the price of electricity. Issues of temporality of practices and synchronisation imply that the timing of people's activities result in peak electricity demand. Changes to the timing of energy demand could only be triggered 
by non-discretionary factors, such as practices, levels of occupancy, location and number of occupants. Flexibility in social practices (and consequently peak electricity demand) might be searched for in the temporal ordering, sequencing and synchronicity of people's doings ${ }^{11,12}$.

Empirical studies on residential energy demand have tended to focus on one or several behavioural or social factors either causing or resulting in peak demand. The physical-technicaleconomic modelling work, which has dominated energy analysis over the past 30 years or so, places less emphasis on human occupants and more on building thermodynamics and technology efficiencies ${ }^{13}$. The technical and price data, along with the modelling techniques typically used in energy demand research imply that the material, visual and physical tend to prevail over the variable and correlational ${ }^{14}$. The preponderant aspiration of existing studies has been to model and forecast peaks in household energy consumption rather than describe patterns and understand the cause of peak electricity demand ${ }^{15,16}$.

We suggest placing the timing of the consumption of energy services in support of social practices at the centre of research investigating the relationship between people and peak electricity demand. Two distinct disciplinary perspectives epitomise how, in social theory, time -in terms of temporal allocation of human tasks, routines and activities- has been recognised as playing a major role in peak electricity demand. First, in time geography, time budget is seen as a concept delimiting the time available for discretionary activities ${ }^{17}$. Second, concepts of squeezing time and hotspots of energy consumption have also been considered through the lenses of social practice theories ${ }^{18}$. At a broader level, taking a social science approach to the time and timing of practices, and hence demand, contributes to an understanding of how social and temporal patterns can inform demand side management programmes, to provide further flexibility to the system.

\section{Methodology}

\section{Time use and locational data}

A recent time use survey (Trajectory) was purchased from private consultants for this analysis. The dataset consists of 244 respondents (extracted from a full Trajectory sample of 500 respondents) recruited from panel data in the cities of London, Manchester, Birmingham, Cardiff and Glasgow who carried GPS devices for up to 3 days, collecting 10 minute interval data on location. 
Geographic information was generated from a portable GPS tracking device used for the Trajectory data collection, a GL100 A-GPS Locator, which transmitted data every 5 seconds. However, if a GPS device was inside a building and could not send data at that time, the last recorded GPS coordinate was taken as the location. This is because GPS devices usually require an unobstructed path to the sky in order to communicate with GPS satellites, which means that they do not work inside buildings or tunnels, and may have a weak signal inside forests or close to tall buildings $^{19}$. In total, the data presented in this paper are derived from a sample of 649 days of data. Diary information was collected from a questionnaire completed by respondents the day after they wore their GPS devices, revealing what people were doing for each 10-minute interval. This activity data is categorised according to one of 38 codes for primary activities performed by respondents (Table 1). Basic demographic information about the respondents, including age, gender, individual income and household income is included in the dataset. Questions about what respondents were doing, with whom, if their day was typical, whether they felt rushed, and if they were enjoying themselves, were also part of the survey which was conducted in this study. In order to focus on how peaks are constructed by the configuration of social practices around working patterns, those aged 65 or over, weekends and data days declared by respondents as non-typical were excluded from the analysis. The final sample analysed therefore comprised 153 respondents, covering 175 data days. An additional methodological endeavour of this work consists of linking time use activities to greenhouse gas intensities. One of the methodological implications of this is that practices and people's activities are given a quantitative value. The methodological details of this part of our work are explained in the section 'Deriving greenhouse gas intensity from time use data'.

Table 1: Primary activity categories used in the Trajectory time use diary

\begin{tabular}{|ll|}
\hline Activity code & Description \\
\hline 1 & Sleeping \\
3 & Resting (doing nothing, "time out") \\
4 & Washing, dressing/undressing etc. \\
5 & Eating or drinking/having a meal (at home/away from home) \\
\hline
\end{tabular}




\begin{tabular}{|c|c|}
\hline 6 & Cleaning, tidying house \\
\hline 7 & Washing, ironing or mending clothes etc. \\
\hline 8 & Maintenance of house, DIY, gardening \\
\hline 9 & Pet care (mark walking the dog here and as secondary exercise) \\
\hline 10 & Travelling: walking/jogging \\
\hline 11 & Travelling: cycle \\
\hline 12 & Travelling: car \\
\hline 13 & Travelling: scooter/motorcycle \\
\hline 14 & Travelling: bus/tram \\
\hline 15 & Travelling: train/tube \\
\hline 16 & Travelling: other \\
\hline 17 & Work for your job (includes paid and unpaid overtime, work brought home) \\
\hline 18 & Formal education \\
\hline 19 & Recreational courses and study \\
\hline 20 & Voluntary work for or on behalf of an organisation, charity or sports club \\
\hline 21 & Caring for/looking after and playing with own children \\
\hline 22 & Caring for/looking after other children \\
\hline 23 & Helping or caring for adults who live with you \\
\hline 24 & $\begin{array}{l}\text { Helping or caring for other adults who don't live with you (not as voluntary } \\
\text { or paid work) }\end{array}$ \\
\hline 25 & $\begin{array}{l}\text { Shopping (incl. internet shopping), banking (incl. internet banking), post- } \\
\text { office, plumber etc. }\end{array}$ \\
\hline 26 & Health care (includes visiting doctor, dentist, optician) \\
\hline 27 & Watching TV and videos/DVDs, listening to radio or music \\
\hline 28 & Reading \\
\hline 29 & Playing sports, exercising \\
\hline 30 & Spending time with friends, family, neighbours at home or at their homes \\
\hline 31 & Going out with friends, family, neighbours (e.g. to the pub, restaurant etc.) \\
\hline 32 & $\begin{array}{l}\text { Contact with friends and family by telephone, text, e-mail, instant message } \\
\text { or letter }\end{array}$ \\
\hline 33 & Visits to cinema, theatre, concerts, sporting events, museums, galleries, \\
\hline
\end{tabular}




\begin{tabular}{|ll|}
\hline 34 & historical monuments, library etc. \\
35 & Meetings (includes political or other meetings) \\
& Church (includes attending church, temple, mosque, synagogue, or other \\
36 & religious meetings or praying) \\
37 & Hobbies and other leisure activities \\
38 & Using a computer or accessing the internet \\
\hline
\end{tabular}

The Trajectory dataset was chosen mainly for three reasons. First, the presence of GPS data enables the benchmarking of the location of respondents' households (taken to be the location where they indicated that they sleep at night), which is vital to conduct analysis on active home occupancy; describe patterns of working and commuting; and examine how people move around in terms of distance travelled, time spent travelling, and mode of transport in relation to time use activities at peak and off-peak times. Second, we conducted a pilot evaluation of a preliminary sample of 50 respondents' time use diaries (also extracted from the complete Trajectory sample of 500 respondents), which presented credible results in terms of what activities are carried out at peak times, variation between morning and evening peaks; variation between different days of the week; socio-demographic attributes of the population and with whom activities were carried out. However the key advantage of this data is that it is the most recent UK time use dataset available. The alternative was to work with UK Time Use Survey data for $2000^{20}$ or $2005^{21}$, which would not be indicative of current practices.

\section{Assessing flexibility: flexibility index}

In combining separate measures of the extent of variation in what people are doing during periods of residential peak electricity demand, the methodology aims to determine what these patterns imply for flexibility and for the potential to shift some peak time activities to other parts of the day. To that effect, a flexibility index has been developed, dependent on the following conditions and assumptions in relation to four component indices. The methodological features of the flexibility index are explained in this section and set out in Table 2. 
The first component index consists of a variation index capturing how dispersed activities are throughout the day. A lower variation index implies that a lower number of activities are distributed through the day, making it less difficult to move activities to different times of the day, contributing to higher flexibility. This reflects the concepts of hotspots and squeezing time, which imply that it is more difficult to shift the timing of activities when these are numerous in a short amount of time ${ }^{22}$. The second component index implies that a high level of synchronisation with other respondents reveals how social practices converge in time and are difficult to shift. A lower synchronisation index (excluding sleeping) implies lower societal constraints, contributing to higher flexibility. This is an empirical representation of what is stated in Section 2: peaks in residential electricity demand occur because of the simultaneous activities of many people at the same time. High levels of synchronisation are indicative of a time of the day in which there is more hurriedness and higher societal constraints to move activities in time ${ }^{23}$. The third component index consists of a shared activities index: a higher time spent on one's own, expressed by a higher non-shared activities index (Table 2), implies that there is lower simultaneity of loads and withinhousehold synchronisation, making it less difficult to move shared activities in time, hence contributing to higher flexibility. Fourth, spatial mobility and active home occupancy indices (Table 2) measure whether people move around much or stay in the home for extended periods of time. Shifting loads for those who spend little time in the household is counterintuitive. Lower spatial mobility at a given time and lower active home occupancy for an extended period of time imply that there is more time to do things, leading to higher flexibility.

The four component indices have been calculated for five time periods of equal length, capturing working weekdays from morning to evening peaks: 7am - 9.50am; 10am - 12.50pm; 1pm 3.50pm; $4 \mathrm{pm}-6.50 \mathrm{pm}$; and $7 \mathrm{pm}-9.50 \mathrm{pm}$. In addition, the component indices are un-weighted and non-normalised. This means that consistently high values for one component index will influence the flexibility index more than consistently low values for another component index. This is because this paper does not aim to understand individuals' flexibility, but rather to explore flexibility in relation to social practices.

Table 2: Overview of flexibility index and its components

Index name $\quad$ Brief explanation of what Calculation method (for each




\begin{tabular}{|c|c|c|}
\hline & the index measures & $\begin{array}{l}\text { demographic, over a given time } \\
\text { period) }\end{array}$ \\
\hline $\begin{array}{l}\text { (1) Synchronisation } \\
\text { index (SI) }\end{array}$ & $\begin{array}{l}\text { Synchronicity with other } \\
\text { people. }\end{array}$ & $\begin{array}{l}\text { Equal to } 1 \text { minus the Shannon's } \mathrm{H} \\
\text { entropy index }{ }^{24} \text {. SI Is a function of } \\
\text { time t per activity i and the number } \\
\text { of individuals who are in i at } t \text {. }\end{array}$ \\
\hline $\begin{array}{l}\text { (2) Variation index } \\
\text { (VI) }\end{array}$ & $\begin{array}{l}\text { Variation of activities, } \\
\text { consistency or dispersion of } \\
\text { activities over time. }\end{array}$ & $\begin{array}{l}\text { Average number of unique activities } \\
\text { for each respondent, divided by the } \\
\text { total possible number of activities } \\
\text { (i.e. } 38 \text { time use codes). }\end{array}$ \\
\hline $\begin{array}{l}\text { (3) Non-shared } \\
\text { activities index (NSAI) }\end{array}$ & $\begin{array}{l}\text { The extent to which } \\
\text { respondents were carrying } \\
\text { out activities on their own, } \\
\text { compared to performing } \\
\text { them in the company of } \\
\text { others. }\end{array}$ & $\begin{array}{l}\text { Average proportion of respondents } \\
\text { who were on their own. }\end{array}$ \\
\hline $\begin{array}{l}\text { (4a) Active home } \\
\text { occupancy (AO) }\end{array}$ & $\begin{array}{l}\text { When people were at home } \\
\text { and were carrying out } \\
\text { activities which consumed } \\
\text { electricity. }\end{array}$ & $\begin{array}{l}\text { Occupants were assumed to be } \\
\text { active if they were performing one } \\
\text { of eight activities (see 'Mobility and } \\
\text { occupancy indices' section below) } \\
\text { when it was highly likely that } \\
\text { respondents were at home } \\
\text { (confirmed through comparison } \\
\text { with respondents' 3am location). }\end{array}$ \\
\hline $\begin{array}{l}\text { (4b) Spatial mobility } \\
\text { index (SMI) }\end{array}$ & $\begin{array}{l}\text { Relative mobility of } \\
\text { respondents in terms of } \\
\text { number of different locations } \\
\text { travelled to over time. }\end{array}$ & $\begin{array}{l}\text { Average number of unique } \\
\text { locations divided by the maximum } \\
\text { number of unique locations for any } \\
\text { one respondent. }\end{array}$ \\
\hline (5) Flexibility index & Provides an indication of the & Flexibility Index = [(Non-Shared \\
\hline
\end{tabular}




\begin{tabular}{|lll|}
\hline (FI) & potential to shift electricity & Activities $)+($ Active home \\
demand and is derived from & occupancy - Spatial Mobility $)+(1-$ \\
four other indices: & Synchronicity $)+(1-$ Variation $)] / 4$ \\
synchronisation, variation, & Or: \\
sharing and mobility / active & $\mathrm{FI}=[(\mathrm{NSAI})+(\mathrm{AO}-\mathrm{SM})+(1-\mathrm{SI})+(1-\mathrm{VI})]$ \\
home occupancy. & $/ 4$ \\
& \\
\end{tabular}

Capturing dispersion of activities - variation index

A variation index has been developed as a measure of consistency or dispersion of activities over time. The basic idea is to capture how fragmented activities are throughout the day and relate this information to flexibility. The variation index is calculated as the average number of unique activities carried out by each respondent divided by the total possible number of activities (38 time use codes) within a given demographic group, in a specified period of time. In this case the calculation was restricted to weekdays that respondents reported as 'typical'. The index used here is essentially equivalent to 'variation' as applied by Vrotsou \& Forsell ${ }^{25}$.

\section{Synchronicity with other people: synchronisation index}

We derive a synchronisation index as the difference between 1 and the standardised Shannon's H - an established measure of entropy in time use studies. The Shannon's H entropy index ${ }^{24}$ states the following:

$$
\mathrm{H}_{\mathrm{t}}=-\sum_{\mathrm{i}=1}^{\lambda} \gamma_{\mathrm{ti} \ln \left(\gamma_{\mathrm{ti}}\right)}
$$

where $\lambda$ is the number of different states, $i$ (i.e. activity codes considered), $t$ is the time of interest (i.e. 10-minute time slot), and $\gamma_{t i}$ is the number of individuals who are in state $i$ at $t$. $H_{t}$ equals 0 when all individuals are in the same state and $\ln (\lambda)$, so that individuals are evenly distributed among the $\lambda$ states. The higher $H_{t}$, the lower the homogeneity of state distribution at $t$. Conversely, a low entropy index means that all the individuals are in the same state (e.g. watching TV) at the same time. The index can be standardised as a percentage value relative to the 
maximum possible value $(\ln (\lambda))$, thus allowing a comparison of data in different activity coding schemes. The index should not be affected by the ratio of observations/ $\lambda$ (issue of sparseness), due to the number of activities not performed at time $t$, since by definition $\gamma_{t i}=0$.

\section{Doing things with others: Shared activities index}

Although time use data reveal the activities of one individual, unless they live in a single person household, the impact of their activities on energy consumption at home depends upon their interaction with other household members. The respective occupancy patterns of household members affect who is doing which activities, whether they are shared or conducted separately and whether they are simultaneous or distributed at different times of the day. Ellegard and Palm ${ }^{26}$ describe this in terms of the concept of 'household projects', i.e. the agreed division of labour within households for shared goals. This perspective has the advantage of overcoming a limitation of occupancy-based energy demand modelling where occupants are treated as units ${ }^{27}$. In those models, each individual comes with his/her own stochastic probability of switching on and off appliances, and the interaction with other occupants is not represented.

A shared activities index is reversed in order to measure the average proportion of respondents in a given demographic group who were on their own during specific time periods. This is termed the 'Non-shared activities index' (Table 2). From the dataset it is possible to derive with whom respondents were with at different times of the day. For each 10 minute time slot, respondents were asked at first if they were with someone or on their own, and in case of the former, who they were with.

\section{Mobility and occupancy indices}

Attempts to combine people's activities in time and space are not new. Time geography approaches visualise the 'space-time path' of individuals to understand how their behaviour varies according to their position in time and space. In transport research, 'space-time cubes' can be used to represent the intersections between several individuals, across their respective spacetime paths ${ }^{28}$. In time use research, Ellegård ${ }^{29}$ applied the time geography approach to routine daily activities to identify activity patterns in time use diary data. In the present study, the spatial mobility index normalises the average number of unique locations for each demographic subgroup by dividing the average by the maximum number of unique locations for any one 
respondent in any one of the five time periods (7am - 9.50am; 10am - 12.50pm; $1 \mathrm{pm}-3.50 \mathrm{pm}$; $4 p m-6.50 p m ;$ and 7pm-9.50pm).

Initial analysis of the GPS (Global Positioning System) co-ordinates coded to the 10-minute diary data revealed challenges with the resolution and meaningfulness of the location data due to the method of coding: a change in location was not registered unless a respondent had been in one place for a minimum of five minutes. Therefore, it was necessary to obtain the original GPS data in KML (Keyhole Markup Language) files format, and match these to the 10-minute diary data using an alternative approach. Each location data point - longitude/latitude/time - in the KML file was randomly assigned to the respective 10 minute slot in the time use diary. Random matching was applied because the KML data recorded between 0 to 120 locations for every 10 minute time slot, with KML locations (i.e. longitude/latitude and time) missing for just under half of all time slots in the Trajectory diary dataset. This means that for all the 10-minute diary time slots (a total of 93,456 records), the combined data (time use diary linked to KML data) had 41,914 records. While there was under-reporting of KML (GPS) data with respect to the diary data; this is often the case in the literature ${ }^{30,31}$, due to the challenges of using GPS technologies to measure movement behaviour. Elsewhere, GPS data has been found to capture more trips than the National Travel Survey travel diary, although not all trips reported in this diary were recorded by GPS devices ${ }^{32}$.

The reasons for analysing occupancy are twofold. First, in research on energy demand modelling occupancy is used as a proxy for energy demand ${ }^{33,34}$. Second, occupancy can also be a point of intersection between practices in the household and people's movement. Active home occupancy has been defined as the time when people are at home but not asleep by Richardson et al. ${ }^{35}$, who operationalised this concept by inputting data from the 2000 UK Time Use Survey to generate a stochastic model of active home occupancy in UK residences. López-Rodríguez et al. ${ }^{36}$ followed a similar approach, simulating peaks of active home occupancy and associated TV electricity consumption from the Spanish Time Use Survey (2009-2010).

In this paper, active home occupancy is calculated through GPS data as the rate of people at home and not resting or sleeping. It is assumed that the respondents' households correspond to their location at 3 AM combined with the activity 'sleeping'. The occupancy rate was calculated as the average percentage of people at home during each time period, and was taken to include the 
following activity codes: sleeping; resting (doing nothing, 'time out'); washing, dressing/undressing etc.; preparing food and drinks, cooking, washing up; cleaning, tidying the house; washing, ironing or mending clothes etc.; maintenance of the house, DIY, gardening; watching TV and videos/DVDs, listening to radio or music. The figures generated were validated through comparison with 21 respondents' locations at 3am, which was found to be approximately equal to the 'activity-based' home locations for respective respondents at a positional accuracy of $1.1 \mathrm{~km}$. To derive active home occupancy, sleeping or resting were excluded.

\section{Deriving greenhouse gas intensity from time use data}

The range of potential techniques to match time use data to energy consumption are predominantly limited to associating particular activities to electrical output from appliances. A difficulty with the Trajectory dataset is that the 38 activity codes are often too broad to permit meaningful matching with electricity consumption from specific appliances. Conversely, Druckman et al. ${ }^{37}$ calculated greenhouse gas intensities for broad activity categories derived directly from the UK Time Use Survey (UKTUS) $2005^{21}$ which match Trajectory activity codes (see Table 3). Following the distinction between direct and embedded energy use ${ }^{38}$, GHG emissions from direct household energy demand (presented in the section below entitled 'Linking time use data to household energy consumption and greenhouse gas intensity') were derived from the UK Environmental Accounts ${ }^{39}$ and the Digest of United Kingdom Energy Statistics ${ }^{40}$ using DECC ${ }^{41}$ energy consumption data tables to allocate emissions to space and water heating, lighting and electrical appliances.

All the limitations are detailed in Table 3. The Trajectory activity code for 'Computer and internet use' is more realistic, averaging 48 minutes per weekday respondents per day (typical days only, 65 year olds or over excluded). Therefore, the reallocated GHG intensities have been deducted from the total intensities for these six activities. A separate GHG intensity has then been calculated for 'Computer and internet use', following the same method applied for the other categories in Druckman et al. ${ }^{37}$

Table 3: Matching Trajectory time use activity codes to greenhouse gas intensity categories 


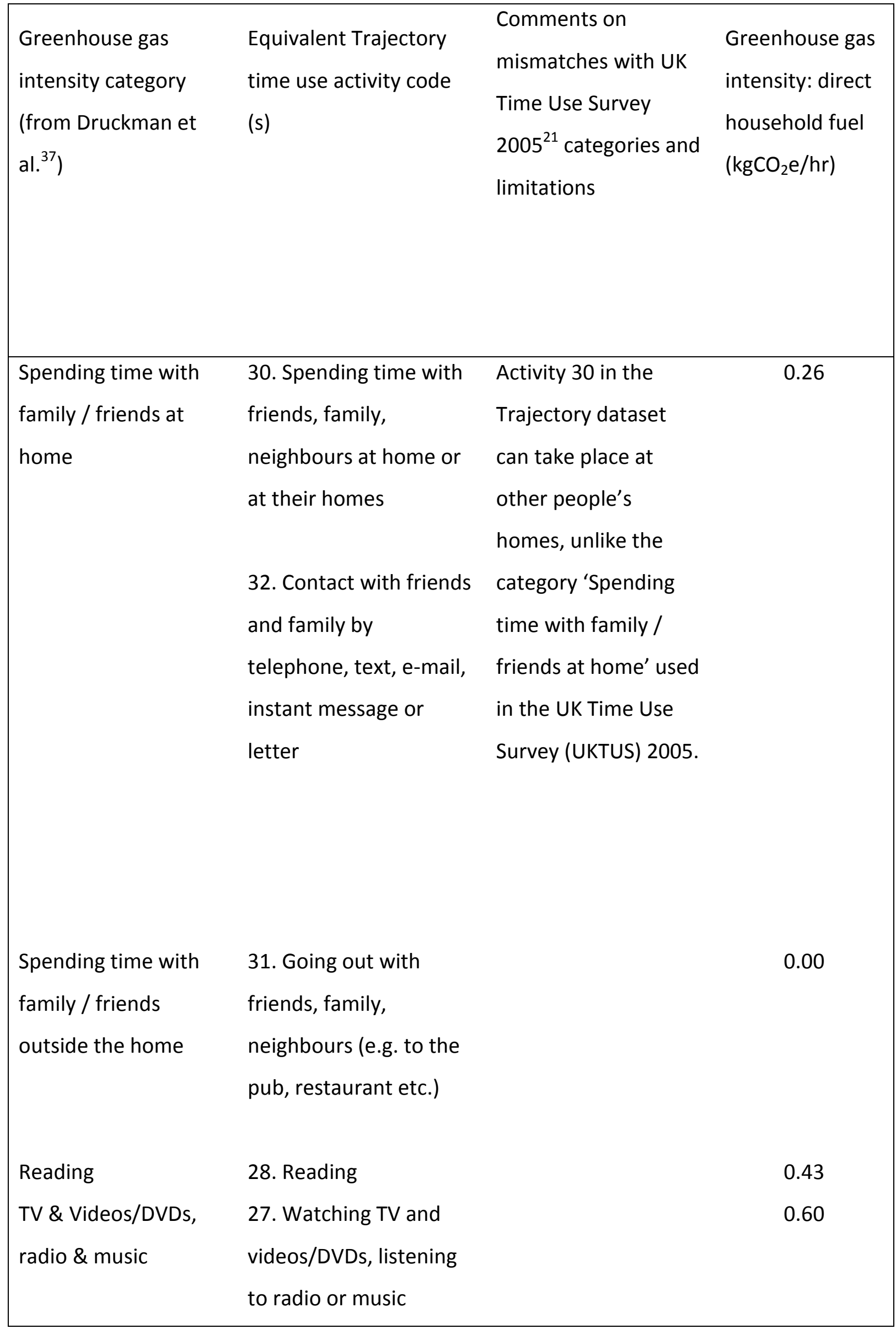



secondary activity to the following six UKTUS 2005 codes: caring for others (own children); spending time with family / friends at home (contact with friends / family); study (formal education); hobbies \& games; shopping; and TV \& Videos/DVDs, radio \& music.

For the purposes of applying the GHG intensities to the Trajectory data, the intensities corresponding to these reallocations have been subtracted from all six categories above. Instead, a new GHG intensity has been calculated for the Trajectory code 'Using a computer or 


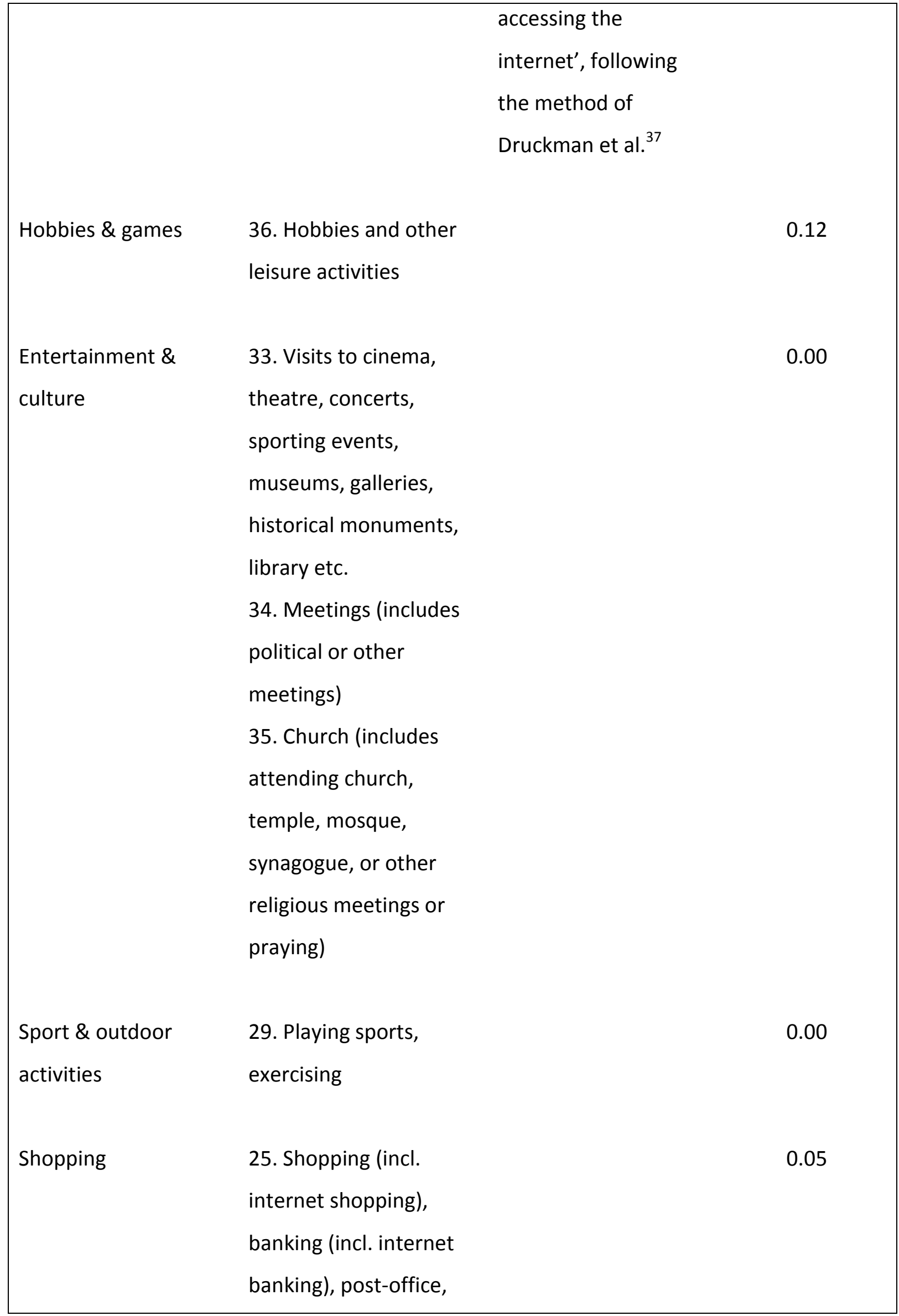




\section{plumber etc.}

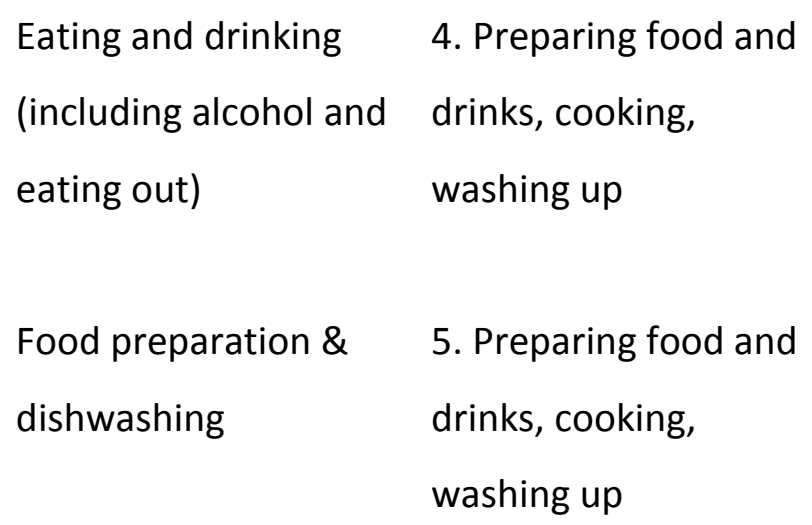

(including alcohol and drinks, cooking,

8. Maintenance of house, DIY, gardening

Pet care

9. Pet care (mark

walking the dog here and as secondary exercise)

\section{Personal care}

3. Washing,

(includes clothes,

dressing/undressing

clothes washing \&

etc.

health care)

7. Washing, ironing or

mending clothes etc.

26. Health care

(includes visiting doctor, dentist, optician)

Caring for others

21. Caring for/looking

Similarly, the 'caring

after and playing with for others' category

own children

comprises the

22. Caring for/looking following UKTUS 2005 


\begin{tabular}{|c|c|c|c|}
\hline & $\begin{array}{l}\text { after other children } \\
\text { 23. Helping or caring for } \\
\text { adults who live with you } \\
\text { 24. Helping or caring for } \\
\text { adults who live with you }\end{array}$ & $\begin{array}{l}\text { activity codes: 'caring } \\
\text { for own children'; } \\
\text { 'caring for other } \\
\text { children'; 'caring for } \\
\text { adults in own } \\
\text { household'; 'caring } \\
\text { for adults in other } \\
\text { households' }\end{array}$ & \\
\hline Study & $\begin{array}{l}\text { 18. Formal education } \\
\text { 19. Recreational } \\
\text { courses and study }\end{array}$ & $\begin{array}{l}\text { Formal education } \\
\text { outside the home } \\
\text { excluded from } \\
\text { Druckman et al. }{ }^{37} \\
\text { GHG intensities. }\end{array}$ & 0.00 \\
\hline Sleep \& rest & $\begin{array}{l}\text { 1. Sleeping; } \\
\text { 2. Resting (doing } \\
\text { nothing, "time out") }\end{array}$ & & 0.08 \\
\hline Commuting & $\begin{array}{l}\text { 10. Travelling: } \\
\text { walking/jogging } \\
\text { 11. Travelling: cycle } \\
\text { 12. Travelling: car } \\
\text { 13. Travelling: } \\
\text { scooter/motorcycle } \\
\text { 14. Travelling: bus/tram } \\
\text { 15. Travelling: } \\
\text { train/tube } \\
\text { 16. Travelling: other }\end{array}$ & $\begin{array}{l}\text { Trajectory activity } \\
\text { codes are not } \\
\text { separated by } \\
\text { commuting / non- } \\
\text { commuting, although } \\
\text { the purpose of travel } \\
\text { is indicated in some } \\
\text { cases. }\end{array}$ & 0.00 \\
\hline $\begin{array}{l}\text { Work for your job } \\
\text { (includes paid and } \\
\text { unpaid overtime, } \\
\text { work brought home) }\end{array}$ & $\begin{array}{l}\text { 17. Work for your job } \\
\text { (includes paid and } \\
\text { unpaid overtime, work } \\
\text { brought home) }\end{array}$ & $\begin{array}{l}\text { Excluded from } \\
\text { Druckman et al. } \\
\text { GHG intensities. }\end{array}$ & $\mathrm{N} / \mathrm{A}$ \\
\hline
\end{tabular}




\begin{tabular}{|c|c|c|c|}
\hline Voluntary work for or & 20. Work for your job & Excluded from & $N / A$ \\
\hline on behalf of an & (includes paid and & Druckman et al. ${ }^{37}$ & \\
\hline organisation, charity & unpaid overtime, work & GHG intensities. & \\
\hline or sports club & brought home) & & \\
\hline \multirow[t]{3}{*}{ Other } & 38. Other activities & Not assigned a & $\mathrm{N} / \mathrm{A}$ \\
\hline & & specific GHG & \\
\hline & & intensity. & \\
\hline
\end{tabular}

\section{Findings}

The role of socio-demographic variables in characterising peak electricity demand: gender and parenthood

The analysis focuses primarily on the timing and duration of activities during morning (7.00-9.50 AM) and afternoon (4.00-6.50 PM) peak electricity demand periods during weekdays and weekends. Whilst there is a literature focusing, for instance, on gender and energy demand issues both in terms of investment, imports and pricing in energy policy planning ${ }^{42}$ and either services, e.g. use of cookstoves, biogas and solar cookers ${ }^{43}$, domestic work $^{17}$, or appliances ${ }^{44}$, there is not much empirical knowledge about the role of gender in the timing of energy demand. 


\section{Figure 1 - Gender differences in weekday activities}

(a) Men



(b) Women




From a simple split of the data based on gender, Figure 1 shows that there is a higher proportion of men than women in work in the sample, and that women tend to work a shorter day. Compared to men, there is a higher percentage of women cleaning and tidying the house in the morning, driving during the middle of the day, and preparing food in the evening. Conversely, a lower proportion of women use a computer in the evening. What transpires is a generally more fragmented day for women with several, relatively short energy-related activities (see below section 'Variation index').

Households with children are understood to have different patterns of energy demand ${ }^{45}$, although less directly addressed are issues of how parent and non-parent activities vary in relation to the timing of energy demand. Figure 2 shows that more households with children begin work earlier in the morning and finish working, eating and start watching TV earlier than those without children, with an implied earlier contribution to the evening peak of electricity demand. At $5 \mathrm{pm}$, a quarter of respondents without children were still working, compared to a fifth of those with children (Figure 2). 
Figure 2 - Households with or without children: differences in weekday activities

(a) With children

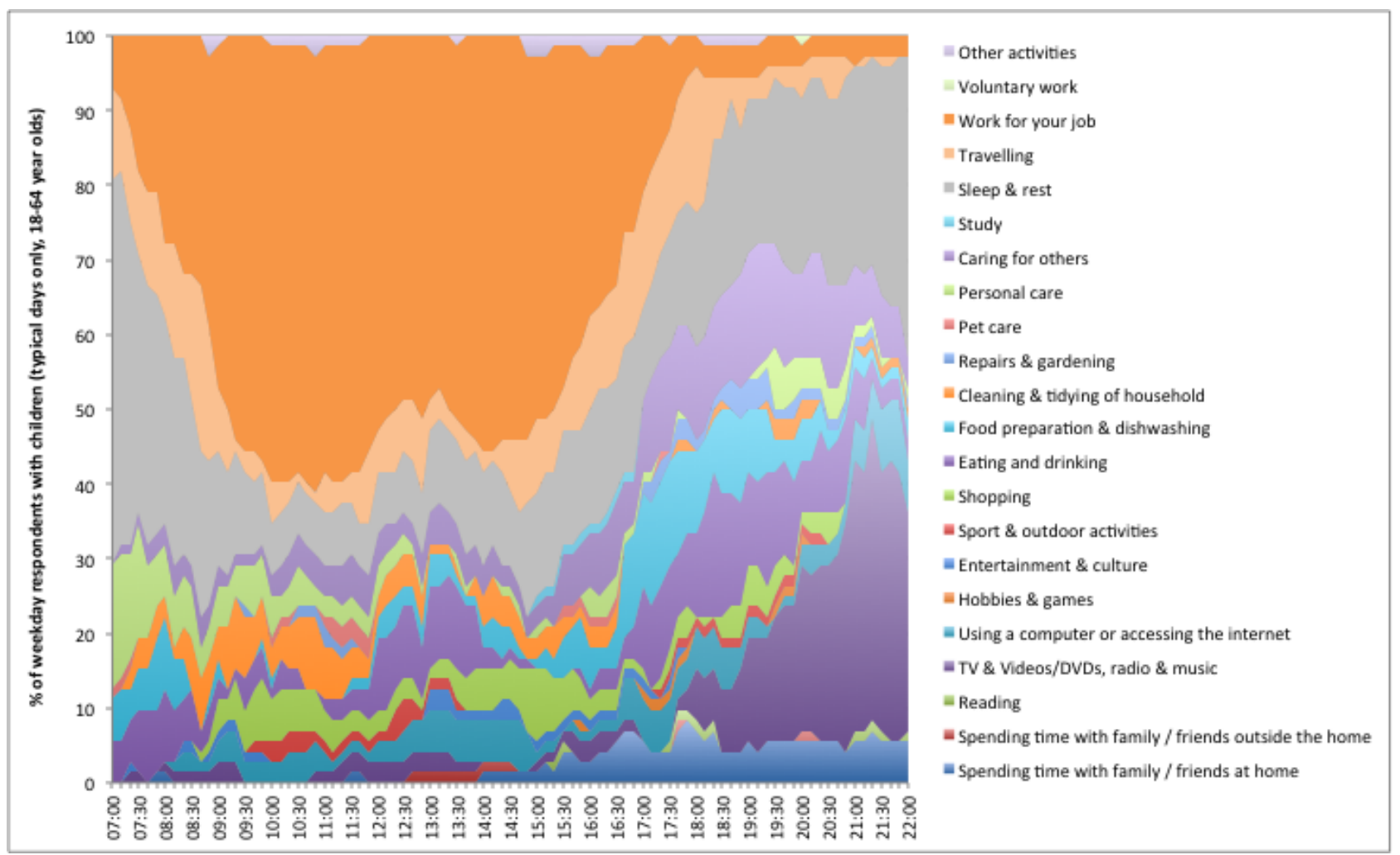

(b) Without children

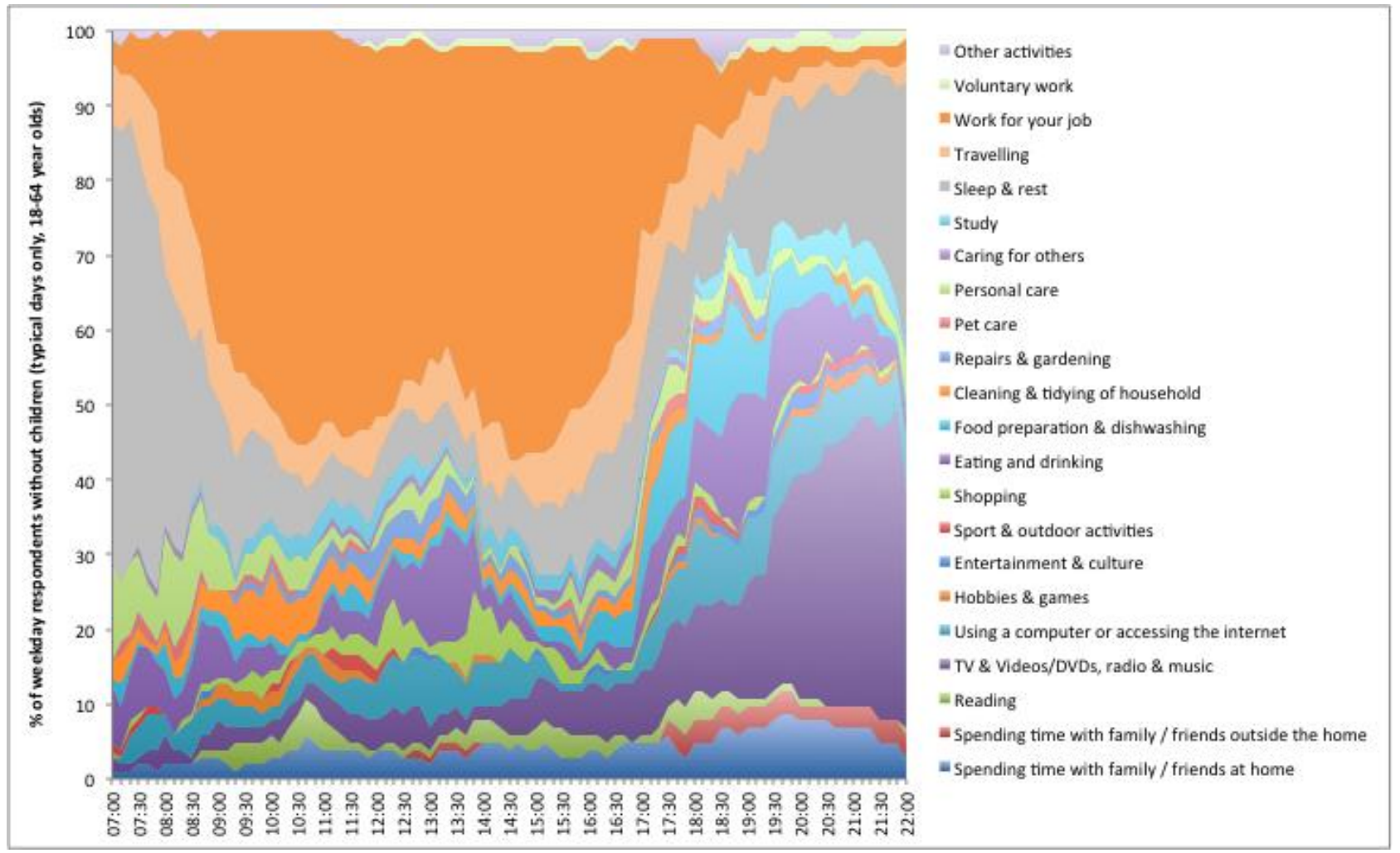




\section{Variation index}

Across all weekday respondents, more activities are performed during the morning peak (7am9.50am) compared to the evening peak $(4 \mathrm{pm}-6.50 \mathrm{pm})$, irrespective of whether they are working or not (Table 4). The average number of different activities performed is highest during these peaks, and lowest in the middle of the day. Females in the sample generally perform more activities over time, even when only men and women in work on the diary days are compared. This is reflected in the variation index, which shows higher indices for women compared to men. Conversely, and perhaps unexpectedly, the average number of activities and the variation index for respondents with or without children is similar, both during the two peak periods, and across the middle of the day. When only respondents who worked on the diary day are considered, the average number of activities performed is higher during the late evening period (7pm - 9.50pm) for those with children than those without. Over 24 hours, working women in the sample perform one more activity on average than men. Women also perform more activities related to unpaid housework than men, which may explain the difference in the range of activities they do over time. Of those who worked, the difference in the proportion of time spent working was not substantially greater for men (32\%) than women (29\%). This gender difference in relative time spent on household work is well established: for example, using time use surveys for 25 OECD countries, Miranda ${ }^{46}$ found that women do more 'unpaid' work in households than men, compensated to some extent by them doing less 'paid work'. While women spend more time on domestic labour, men report more entertainment activities at home (e.g. TV watching and computer games), which is consistent with findings from Ellegard \& Palm ${ }^{26}$.

Table 4 - Variation index (average number of unique activities / total number of activities) by gender and respondents with or without children

\begin{tabular}{|llllll|}
\hline $\begin{array}{l}\text { Demographic } \\
\text { group }\end{array}$ & $\begin{array}{l}\text { 7am - } \\
\text { 9.50am }\end{array}$ & $\begin{array}{l}\text { 10am - } \\
\mathbf{1 2 . 5 0 p m}\end{array}$ & $\begin{array}{l}\text { 1pm - } \\
\mathbf{3 . 5 0 p m}\end{array}$ & $\begin{array}{l}\text { 4pm - } \\
\text { 6.50pm }\end{array}$ & $\begin{array}{l}\text { 7pm - } \\
\mathbf{9 . 5 0 p m}\end{array}$ \\
\hline All males & 0.09 & 0.05 & 0.05 & 0.08 & 0.07 \\
All females & 0.10 & 0.07 & 0.07 & 0.09 & 0.07 \\
All respondents & 0.10 & 0.06 & 0.06 & 0.09 & 0.07 \\
with children & & & & & \\
All respondents & 0.10 & 0.04 & 0.05 & 0.09 & 0.08 \\
without children & & & & & \\
\hline
\end{tabular}




\section{Synchronisation index}

Table 5 shows synchronisation indices by gender breakdown and for households with or without children, including and excluding sleeping, based on the definition of the synchronisation index provided in the section above 'Synchronicity with other people: synchronisation index'. Respondents who said that the day on which they were surveyed was not typical have been excluded. Respondents who were 65 or over have also been omitted, given that the interest here is in the synchronisation of the working age population. Arguably the highest level of synchronisation occurs at night time, when people are sleeping, with a negligible impact on electricity consumption (excluding electric space heating). For this reason, synchronicity of sleeping was excluded from this index measurement. This is not to say that sleeping should be generally dismissed, as it may affect occupancy and demand. For instance, shift-working is common in the UK and has consequences for when people get up and start activities, implying a different synchronisation from others. However, we did not observe this level of shift-work in our dataset.

Synchronisation is higher in the morning than evening peaks, due to the more predictable sequence of activities which take place as respondents get ready to go to work under greater conditions of time squeeze. This is particularly true of men and respondents with children, while the difference is much less marked for women and non-existent for people with no children (Table 5). Men exhibit higher levels of synchronisation during the working day, and lower levels of synchronisation in the evenings compared to women (Figure 3). Synchronisation is higher for respondents with children than those without through most of the day, particularly in the morning (Figure 4).

Table 5 - Summary findings for Synchronisation Index (for all activities excluding sleeping)

\begin{tabular}{|llllll|}
\hline $\begin{array}{l}\text { Demographic } \\
\text { group }\end{array}$ & $\begin{array}{l}\text { 7am - } \\
\text { 9.50am }\end{array}$ & $\begin{array}{l}\text { 10am - } \\
\mathbf{1 2 . 5 0 p m}\end{array}$ & $\begin{array}{l}\text { 1pm - } \\
\mathbf{3 . 5 0 p m}\end{array}$ & $\begin{array}{l}\text { 4pm - } \\
\mathbf{6 . 5 0 p m}\end{array}$ & $\begin{array}{l}\text { 7pm - } \\
\mathbf{9 . 5 0 p m}\end{array}$ \\
\hline All males & 0.44 & 0.55 & 0.53 & 0.30 & 0.34 \\
All females & 0.40 & 0.40 & 0.38 & 0.32 & 0.41 \\
$\begin{array}{l}\text { All respondents } \\
\text { with children }\end{array}$ & 0.47 & 0.52 & 0.50 & 0.34 & 0.40 \\
\hline
\end{tabular}




\begin{tabular}{|llllll|}
\hline $\begin{array}{l}\text { All respondents } \\
\text { without children }\end{array}$ & 0.38 & 0.46 & 0.45 & 0.30 & 0.36 \\
\hline
\end{tabular}

Figure 3 - Relative synchronisation of men compared to women

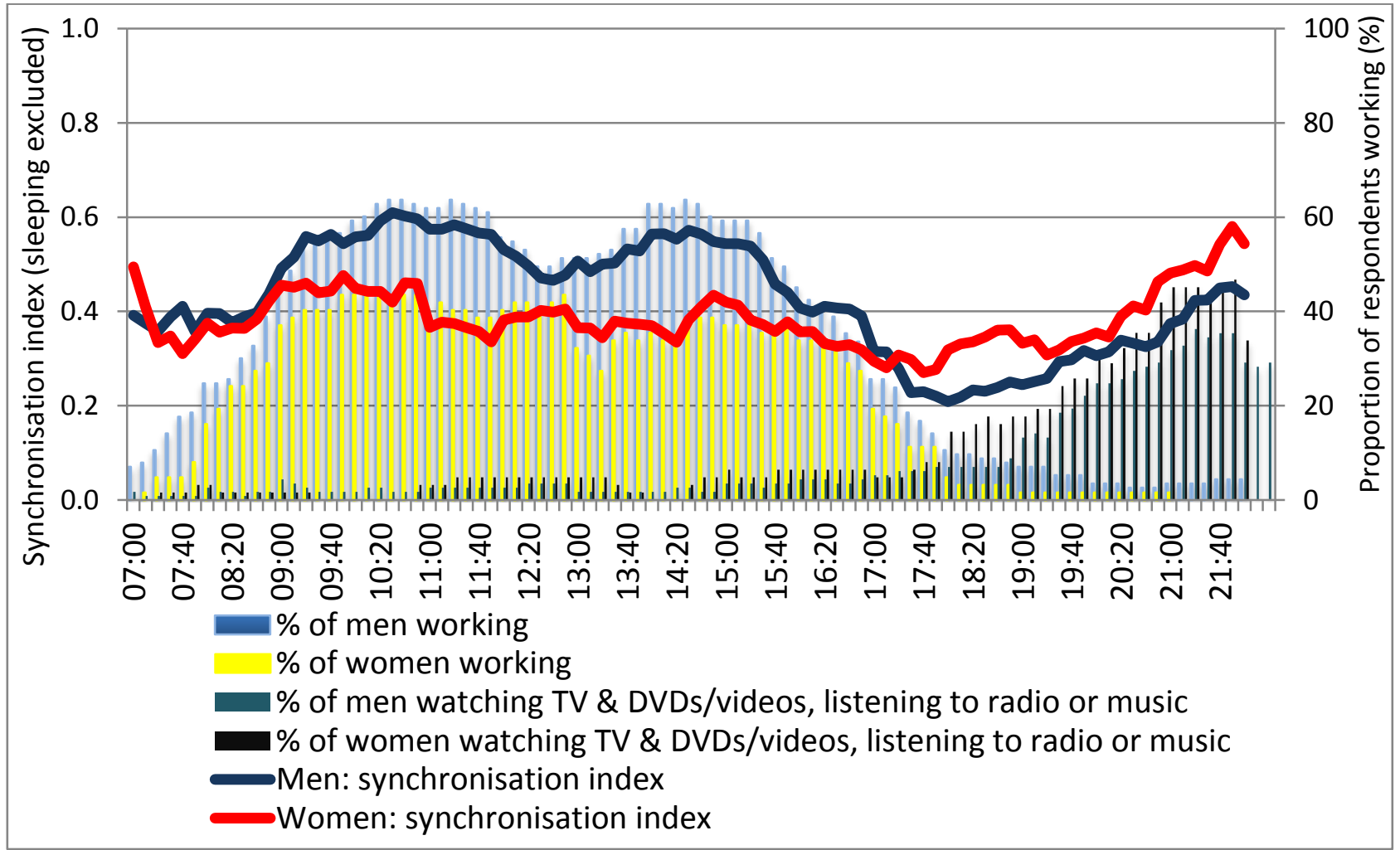

Figure 3 shows that men and women have approximately the same level of synchronisation during the morning peak, after which men throughout the day are more synchronized. Women have higher synchronisation in the evening peak. As work phases out, TV watching ensues, driving synchronization upwards. However, in the evening peak the lowest level of synchronization is reached, meaning that the concept of hotspots is associated with several and diverse activities.

Figure 4 - Relative synchronisation of respondents with children compared to those without children 


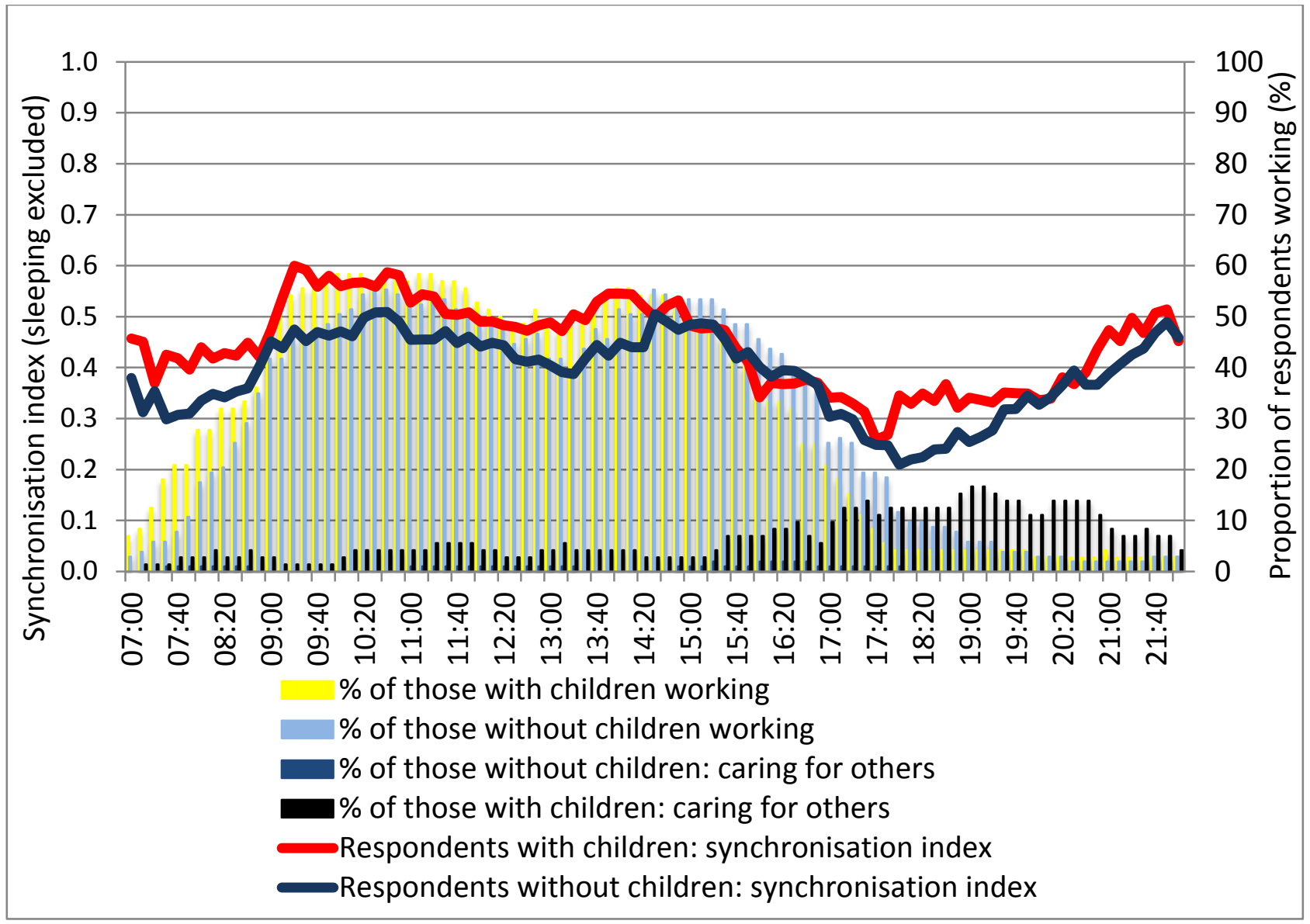

Figure 4 shows that respondents with children are generally more synchronised than those without. For respondents with children, there is higher synchronisation in particular during the morning peak (7am-9.50am), and following this period until $2 \mathrm{pm}$, as well as during the early evening from $6 \mathrm{pm}-7.30 \mathrm{pm}$, compared to respondents without children. Otherwise the synchronisation index is similar for respondents with / without children from 2.30pm to 5.30pm. During the morning peak, synchronisation is highest at 9.20 am for respondents with children, $60 \%$ of whom are working at this time, compared to just over half of people without children. While the higher synchronization of men from 9am to $5 \mathrm{pm}$ reflects the greater proportion of males who are working over this time, women exhibit higher levels of synchronization in the evening, when more females are watching TV. The latter runs counter to the findings of Ellegard \& Palm ${ }^{26}$ on gender differences in domestic entertainment activities mentioned above. Higher levels of synchronization in the early evening for a significant proportion of respondents with children can be linked to time spent 'caring for others', an activity which is minimal in the case of those without children. 


\section{Shared activities index}

In analysing time use data it is recognised that people do not live in isolation. This simple statement has significant implications for micro-level synchronicity (e.g. occupants within the same household) and energy demand - depending on the extent to which there is a shared use of appliances, lighting for cohabited rooms, etc. It also contributes significantly to the narrative on social practices and implications in terms of energy demand. Levels of multi-occupancy are typically addressed by energy modellers via stochastic approaches predicting the probability that any additional tenant/occupant enters or leaves the household for a specific time period.

\section{Figure 5 - Time spent with other people}

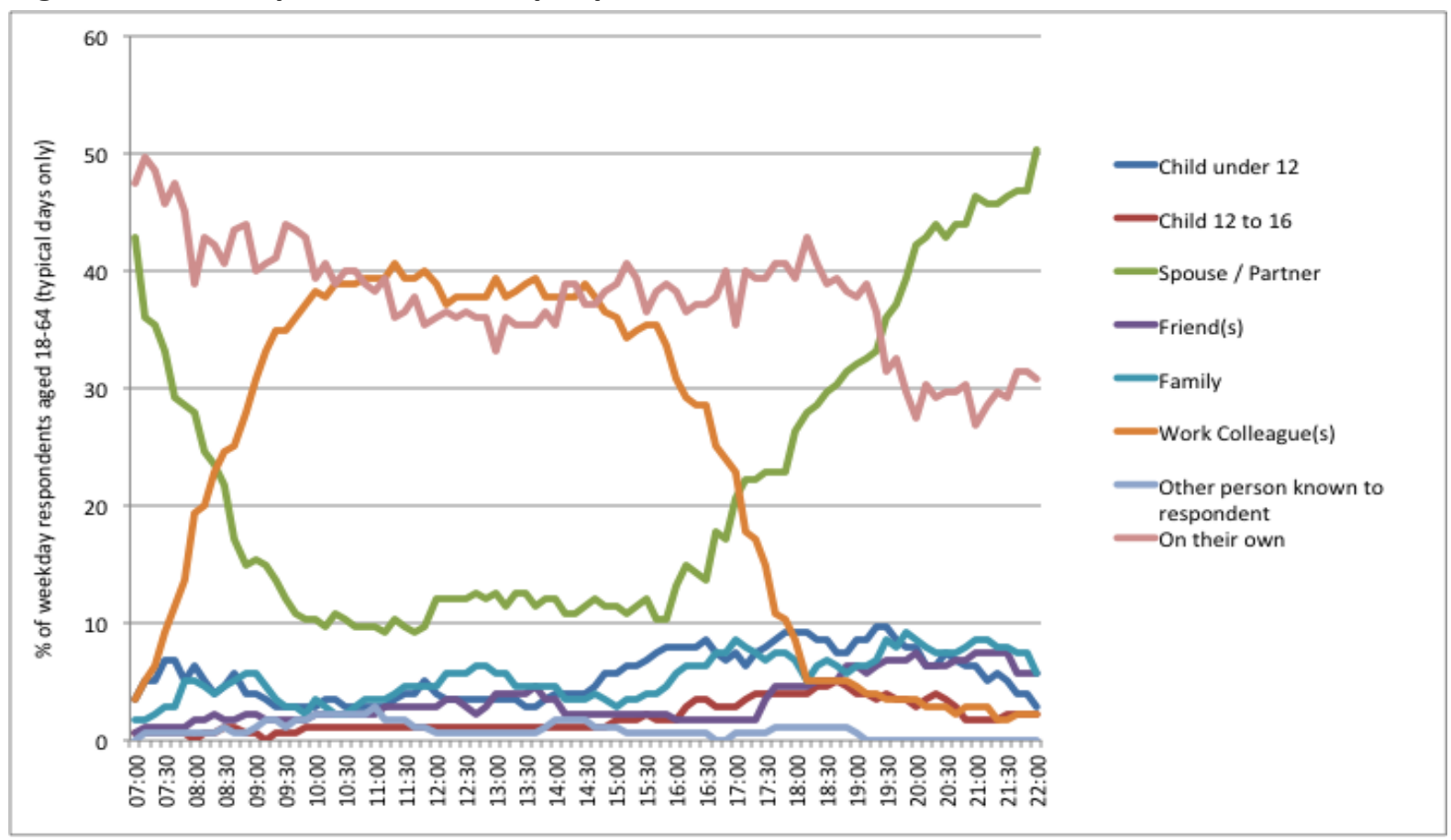

Figure 5 shows the times of the day that respondents aged 18-64 spent with other people on typical weekdays. Perhaps not surprisingly, during weekdays, early morning, evening and night time are often spent with their partner/spouse and children. The rest of the day is predominantly spent with work colleagues and/or by oneself. 
The non-shared activities index (Table 6) demonstrates how a substantially greater percentage of respondents without children were on their own throughout the day compared to those who had children. In addition, a higher proportion of men were on their own between 10am and 6.50pm compared to women. Significantly more females in the sample were with children during this time, particularly those under 12 years old. Time spent alone varies less dependent on whether respondents had children or not, except from $7 \mathrm{pm}-9.50 \mathrm{pm}$, when those without children were significantly less likely to be on their own: for example, $56 \%$ stated that the first person they were with at this time was their partner or spouse.

Table 6: Non-shared activities index, i.e. average proportion of respondents' time spent on their own, by gender and whether or not they have children

\begin{tabular}{|llllll|}
\hline $\begin{array}{l}\text { Demographic } \\
\text { group }\end{array}$ & $\begin{array}{l}\text { 7am - } \\
\mathbf{9 . 5 0 a m}\end{array}$ & $\begin{array}{l}\mathbf{1 0 a m}- \\
\mathbf{1 2 . 5 0} \mathbf{p m}\end{array}$ & $\begin{array}{l}\mathbf{1 p m}- \\
\mathbf{3 . 5 0} \mathbf{p m}\end{array}$ & $\begin{array}{l}\mathbf{4 p m}- \\
\mathbf{6 . 5 0 p m}\end{array}$ & $\begin{array}{l}\mathbf{7 p m}- \\
\mathbf{9 . 5 0 p m}\end{array}$ \\
\hline All males & 0.45 & 0.41 & 0.41 & 0.42 & 0.30 \\
All females & 0.41 & 0.32 & 0.31 & 0.34 & 0.32 \\
$\begin{array}{l}\text { All respondents } \\
\text { with children }\end{array}$ & 0.31 & 0.29 & 0.32 & 0.29 & 0.23 \\
$\begin{array}{l}\text { All respondents } \\
\text { without children }\end{array}$ & 0.52 & 0.43 & 0.41 & 0.45 & 0.37 \\
\hline
\end{tabular}

\section{Spatial mobility and active home occupancy index}

For the purpose of matching geographic data to the resolution of the time use diary, only one KML location occurring within a given 10-minute period was randomly assigned to the equivalent time slot (see section: 'Mobility and occupancy indices'). The upper part of Table 7 shows the spatial mobility of the five time periods presented. Weekday respondents moved around most during the evening peak from $4 \mathrm{pm}$ to $6.50 \mathrm{pm}$, and least in the late evening $(7 \mathrm{pm}-9.50 \mathrm{pm})$. Relative mobility is higher for respondents with children in the morning than those without children, and higher for women and respondents without children from $1 \mathrm{pm}$ to $3.50 \mathrm{pm}$.

Active occupancy rates in the lower part of Table 7 follow expected temporal variations, being lowest during the middle of the day, higher during the morning and evening peaks and highest during the late evening period when spatial mobility is also at its lowest. Active home occupancy is 
consistently greater for women compared to men throughout the day, and higher for respondents with children during the morning peak.Table 7 - Spatial mobility index (= average / maximum number of unique GPS locations) and average rates of active home occupancy per respondent (i.e. $\%$ time spent at home actively consuming electricity and not sleeping or resting)

\begin{tabular}{|c|c|c|c|c|c|}
\hline 1. Spatial mobility & $\begin{array}{l}\text { 7.00am - } \\
\text { 9.50am }\end{array}$ & $\begin{array}{l}\text { 10am - } \\
12.50 \mathrm{am}\end{array}$ & $\begin{array}{l}1 \mathrm{pm} \mathrm{-} \\
3.50 \mathrm{pm}\end{array}$ & $\begin{array}{l}\text { 4pm - } \\
6.50 \mathrm{pm}\end{array}$ & $\begin{array}{l}7 p m- \\
9.50 p m\end{array}$ \\
\hline All males & 0.16 & 0.16 & 0.15 & 0.19 & 0.12 \\
\hline All females & 0.16 & 0.16 & 0.20 & 0.19 & 0.12 \\
\hline $\begin{array}{l}\text { All respondents with } \\
\text { children }\end{array}$ & 0.18 & 0.19 & 0.16 & 0.20 & 0.11 \\
\hline $\begin{array}{l}\text { All respondents } \\
\text { without children }\end{array}$ & 0.15 & 0.15 & 0.18 & 0.18 & 0.12 \\
\hline $\begin{array}{l}\text { 2. Active home } \\
\text { occupancy }\end{array}$ & $\begin{array}{l}\text { 7.00am - } \\
\text { 9.50am } \\
\end{array}$ & $\begin{array}{l}\text { 10am - } \\
12.50 \mathrm{am}\end{array}$ & $\begin{array}{l}1 \mathrm{pm} \mathrm{-} \\
3.50 \mathrm{pm}\end{array}$ & $\begin{array}{l}4 p m- \\
6.50 p m\end{array}$ & $\begin{array}{l}\text { 7pm - } \\
9.50 p m\end{array}$ \\
\hline All males & 0.40 & 0.30 & 0.22 & 0.46 & 0.55 \\
\hline All females & 0.60 & 0.42 & 0.36 & 0.58 & 0.63 \\
\hline $\begin{array}{l}\text { All respondents with } \\
\text { children }\end{array}$ & 0.56 & 0.31 & 0.26 & 0.52 & 0.60 \\
\hline $\begin{array}{l}\text { All respondents } \\
\text { without children }\end{array}$ & 0.42 & 0.36 & 0.28 & 0.51 & 0.56 \\
\hline
\end{tabular}

\section{Linking time use data to household energy consumption and greenhouse gas intensity}

Figure 6 illustrates GHG intensities arising from household energy (gas, electricity, oil and solid fuel $^{41}$ ) for 175 weekday respondents (not aged 65 years or more) who stated that their day was typical. Although GHG intensities are also available for embedded emissions and transport, these are not considered here as the focus is on social practices associated with household occupancy and the potential to manage peaks of residential electricity demand.

As expected, GHG intensities derived from reported activities in Figure 6 reflect the morning and evening peaks (with a smaller lunchtime peak) observed in the time use profiles above. The morning peak in GHG emissions from household fuels is largely due to the time use activity code 'personal care' (i.e. washing and dressing), making breakfast and eating, and cleaning and tidying 
afterwards. In the evening, TV watching and other forms of audio-visual entertainment are the most substantial source of emissions. Cooking and food preparation makes a larger contribution to GHG intensities in the evening than in the morning, while personal care contributes less but is still significant. Nevertheless, the analysis of GHG intensities from the 2005 UK Time Use Survey ${ }^{21}$ in Druckman et al. ${ }^{37}$, highlights that embedded greenhouse gas intensities from personal care are greater than those from direct household energy in this category. Indeed, direct household energy use accounts for less than a quarter of the carbon footprint (measured in terms of GHGs) of an average UK household ${ }^{471}$.

The higher variation in women's daily routines compared to men (see Section 4.2) is immediately apparent in Figure 6. The morning and evening peaks are less distinct in the case of women, due to greater implied occupancy during the day, which can be expressed by continuing energy consumption from personal care through the morning and into the early afternoon. In the evening, GHG emissions from food preparation by women is greater than that from men, while the reverse is true for TV watching and audio-visual entertainment in general. Overall, GHG intensities from direct household energy use are greater for women than for men, which is a consequence of women's higher rate of active home occupancy. As noted above, work has not been included in the GHG intensity categories, and the analysis of variation by gender above suggests that greater energy consumed by women at home is compensated for by men's energy consumption, because they spend more time at work than women. While GHG intensities for housework were higher for women, their emissions for recreation and leisure and from commuting to work were lower than for men. Furthermore, a study of household expenditure in four European countries by Raty \& Carlsson-Kanyama ${ }^{48}$ indicates that men consume more energy from transport and eating out. 
Figure 6a - Greenhouse gas intensity per capita for direct household fuel, male respondents only (typical days, $>64$ year olds excluded)

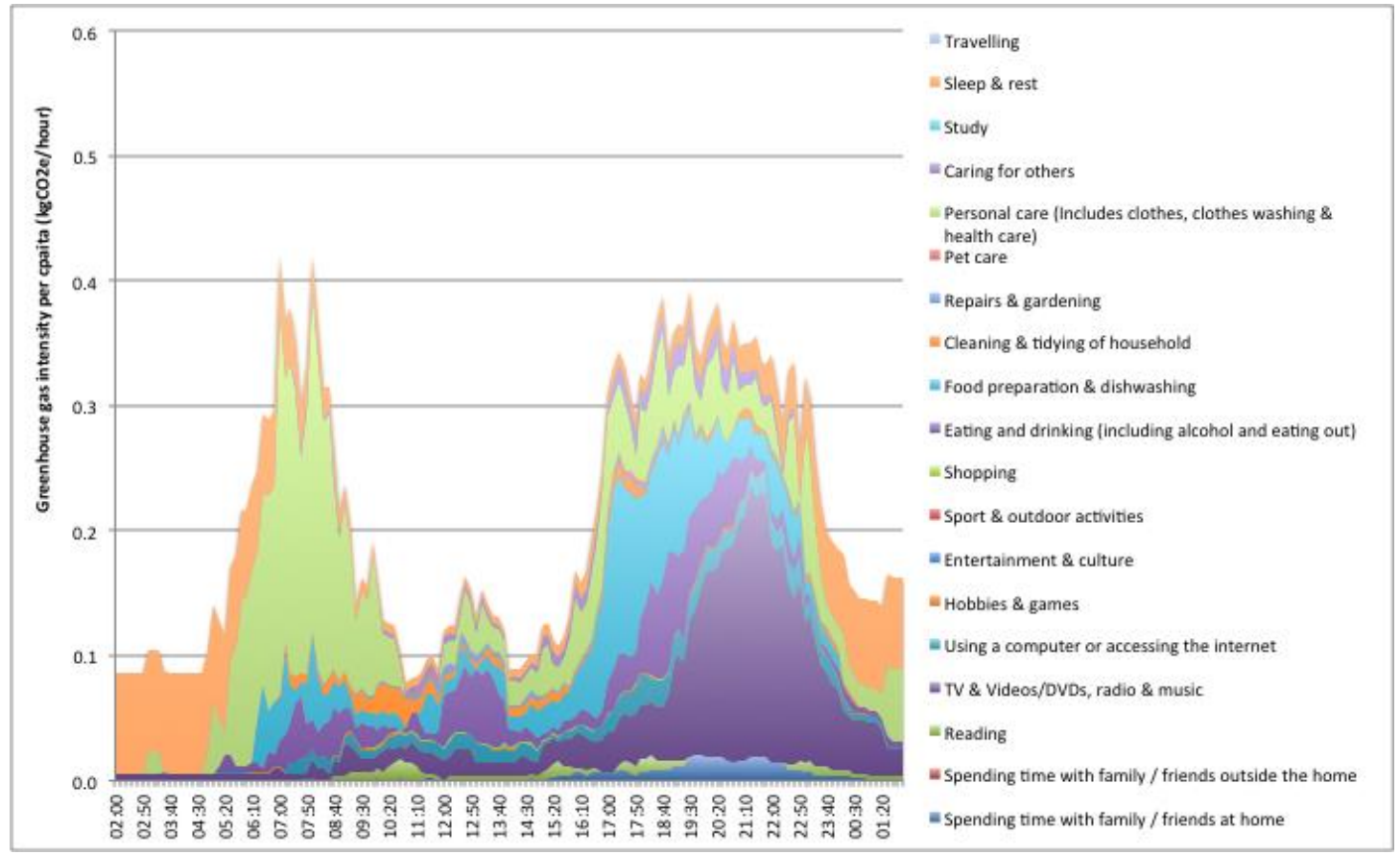

Figure 6b - Greenhouse gas intensity per capita for direct household fuel, female respondents only (typical days, >64 year olds excluded)

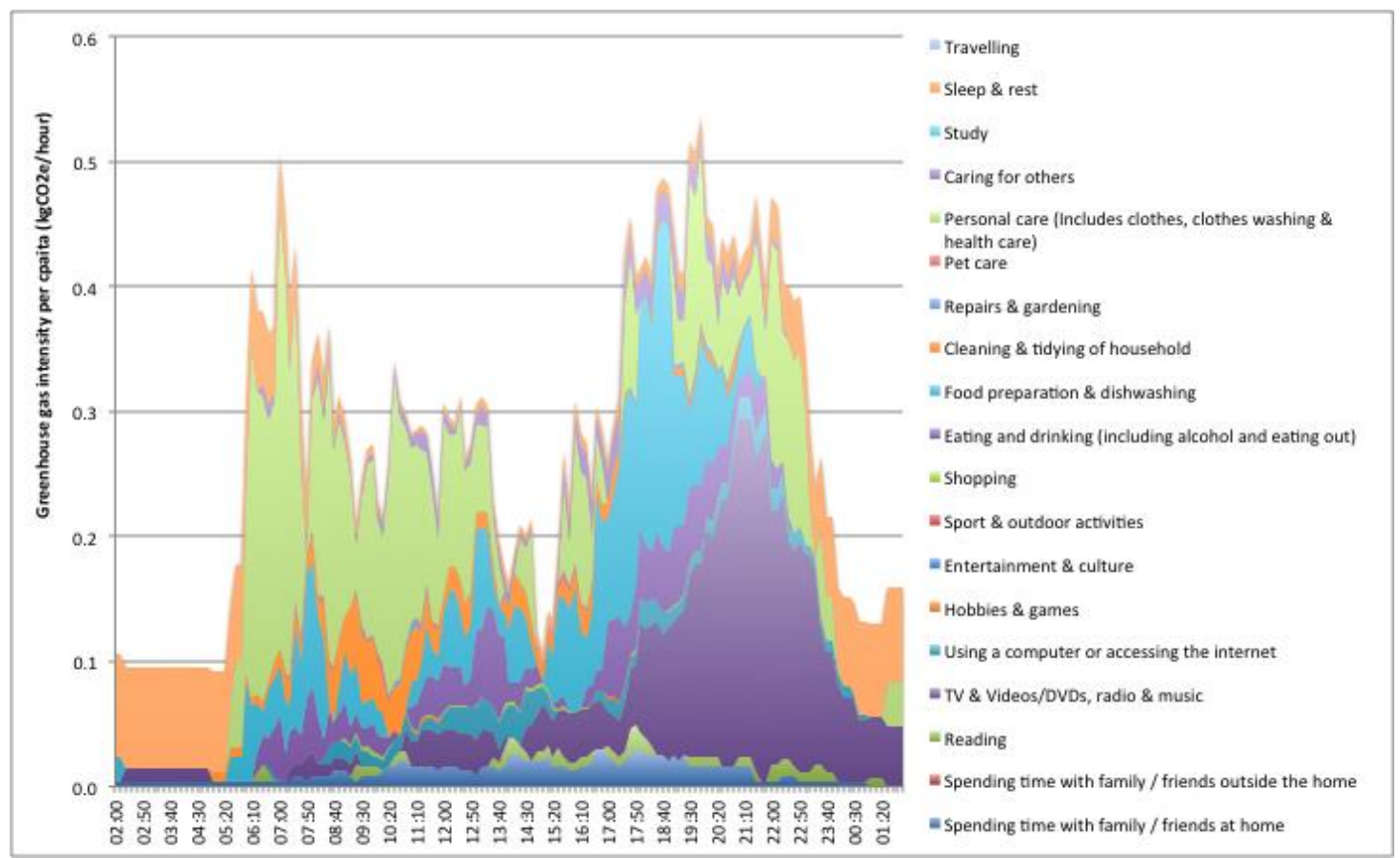




\section{Flexibility index}

Figure 7 and Figure 8 summarise findings for all four component indices and present the results on the flexibility index for men and women, as well for households with and without children, respectively.

Figure 7 - Flexibility index, component indices and GHG intensities for men and women



Figure 7 shows significant differences between men and women in both GHG intensities and flexibility. Throughout the day, women carry out activities associated with higher GHG intensities from household energy use. The flexibility index is generally higher for women, but from the evening peak the flexibility level of men and women converges. This is caused by higher active home occupancy and low synchronisation for women throughout the day, but a higher variation index (showing a shorter duration and higher fragmentation of activities) in the evening. 
Figure 8 - Flexibility index, component indices and GHG intensities for households with and without children

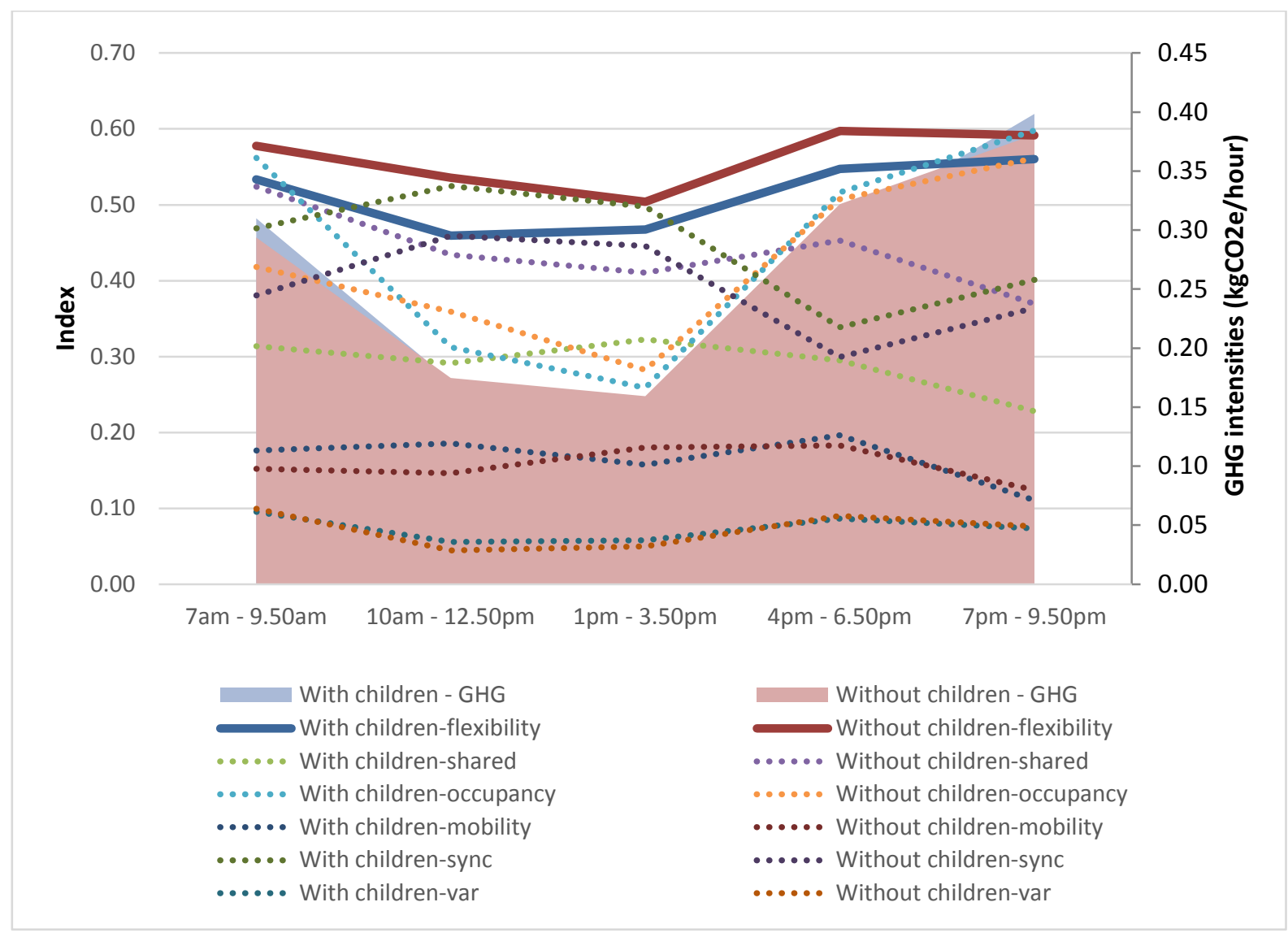

Figure 8 shows that whilst the difference between households with or without children is minimal in terms of GHG intensities, their respective flexibility indices vary significantly. Households with children are associated with a lower flexibility at both peak times and throughout the day.

Overall, the findings suggest that women often initiate evening peak demand through the activities they report. They have a particularly fragmented set of activities at this time of the day although slightly lower than in the early morning. We might therefore conclude that flexibility for women at evening peak is low (although perhaps not as low as in the morning peak). At the time when activities that generate the evening peak ensue, men tend still to be at work or travelling home from work. The lack of occupancy by men exacerbates the low level of flexibility at this time of the day. However, the results also highlight groups for whom there is potentially higher flexibility. For example, the dataset comprises a high proportion of people working from home. This reflects the urban nature of the Trajectory sample and also the trends highlighted by the 
Office for National Statistics ${ }^{49}$, with a home worker rate of $13.9 \%$ of those in work, the highest ever rate in the UK. People working from home correspond to the highest level of flexibility, because their practices are associated with high active home occupancy, low spatial mobility, long duration of a small set of activities mainly not shared with others and low synchronisation with the rest of the population.

Turning to morning peaks, the analysis shows that variation of activities is very high, with sociodemographic groups also featuring high levels of synchronisation. At this time of the day women perform more different activities than men and synchronisation is higher than during evening peaks, particularly for men and families with children preparing to leave home. Occupancy is very high before $8 \mathrm{AM}$ and several activities are shared with others implying a very low level of potential flexibility at this time of day for those aged 18-64 in this sample.

\section{Conclusions}

The dual aim of this paper was to make use of recent UK data on time use to better understand flexibility in residential peak electricity demand by analysing aspects of daily life such as temporal ordering, home occupancy (i.e. time at home), synchronisation between residents of different households, and linking social practices at peak time with GHG intensities. This ambition was complicated by the fact that the metrics for these types of data have traditionally been kept separate. In our methodology we have attempted to develop metrics such as synchronisation indices, active home occupancy and spatial mobility indices as well as the level of sharing and variation of activities at times of peak electricity demand. The use of a main dataset made it possible to extract information from time use diaries (i.e. activity codes) and people's movements (i.e. GPS co-ordinates) and to link these to GHG intensities. This connection has the dual merit of (i) operationalising findings on the distribution of social practices with carbon and electricity demand intensities; and (ii) providing an indication of how time use activities perform in terms of flexibility and carbon intensity. This information may have significant policy implications, as explained below.

The analysis indicates that households with children exhibit greater synchronisation and marginally less variation in their daily routines than households without children, while women's 
activities are more fragmented than men's through much of the day. The length of the working day varies across social groups such as by gender or the presence of children.

The findings of this research are intended to stimulate new thinking around the internal heterogeneity of the domestic activities that generate peak electricity demand in contrast to the dominant 'average' view of a 'typical' household's energy consumption and forms of intervention designed around price. The analysis reported in this paper highlights how the gendered nature of some practices (with substantially different reporting of housework and paid work as well as later evening media use by men and women of working age in this sample) affects flexibility to potentially shift electricity demand. The analysis also draws attention to the structuring effect of work or family commitments on the time and timing of activities which have implied energy demands.

'Synchronicity' of social practices as measured by time use surveys provides an effective way to rethink peak electricity demand as deriving from the simultaneous performance of activities. In addition, the analysis of the sequence and timing of these activities in different social groups starts to reveal some of the possible causes of this simultaneity and to infer some implications for their potential (in)flexibility. The ambition of this paper was to place social practices rather than individuals at the centre of the measurement of flexibility. One reason why we were not able to achieve this fully is because working practices were removed for symmetry with available GHG intensity data. In further analysis there could be merit in trying to compare social practices taking the time use activity as the independent variable.

Examining the fragmentation of morning and evening peaks also represents an innovative way to reveal the relative concentration of different activities at different times of day and for different social groups. For instance, this has implications for dual tariff design, as most Time of Use tariffs use $8 \mathrm{AM}$ as the demarcation time between peak and off-peak ${ }^{50}$. More broadly, this prompts further consideration of the implications of these patterns for the kinds of flexibility that are implicated in demand response.

Limitations of this study 
The findings are subject to a number of limitations related to the nature of the Trajectory dataset which, as a small, urban-based sample, has not been weighted to be nationally representative. As the time use diary was collected a day after respondents carried their GPS devices, a degree of recall error ${ }^{51,52}$ may apply to the activity data. Moreover, the GPS record is not continuous, due to GPS tracking devices losing signal away from open spaces. Due to the wide variation in the frequency of GPS data points, there was no systematic way to match GPS locations to 10-minute time use diary slots, and a random allocation approach was applied. The spatial mobility and activity occupancy indices should therefore be interpreted with a degree of caution, given that they may not incorporate the full extent of mobility of the respondents. The sample of typical weekdays featured in this analysis is a compilation of mostly single diary days collected for different individuals, with a few exceptions, so that they do not incorporate variations by weekday per individual ${ }^{51}$. The diary data also reflects only the activities of individuals, and does not capture activity information for other household members. As such, gender differences in components of flexibility identified in this study are between households, rather than within households. With respect to estimates of GHG intensity, Table 3 presents a detailed list of limitations, with the most important mentioned here. The greenhouse gas intensity data generated is for 2004 , whereas the Trajectory data is for 2011. Secondly, 'work' (voluntary or paid) and formal education taking place away from home were not included as a category in Druckman et al. ${ }^{37}$, while there is only an activity code for 'Travelling' split by mode of travel in the Trajectory dataset, rather than a specific activity code for commuting. This does not compromise the analysis in the section 'Linking time use data to household energy consumption and greenhouse gas intensity', which presents GHG intensities from household electricity use alone. A limitation of the 2005 UKTUS is that it underestimates the average time spent using a computer per day. To compensate for this, computer use was reallocated to six different activities by Druckman et $\mathrm{al}^{37}$.

\section{Implications for the reconfiguration of electricity demand}

From a policy perspective, this work shows how the make-up of peak demand is influenced by areas of policy other than energy per se. This is abundantly clear in the apparent structuring effects of labour market participation and working hours on the nature and timing of evening activities and the consequences for the time and timing of electricity demand. A higher degree of variation in the end-point of working schedules or commuting times might, for example, diffuse evening peak electricity demand, although it may not reduce demand overall. 
From a network operator perspective, the results indicate that areas where there is a higher degree of homogeneity in terms of household characteristics may be prone to more significant local network loads due to the synchronization of electricity-demanding activities. Thus understanding the spatial distribution of these dimensions may provide a substantial step forward for understanding where and how to address them ${ }^{53}$. For instance, combining information about people's activities with where their home is could provide important insights for network reinforcement cost-benefit analysis.

From a research perspective, it seems apparent that any form of large scale household energy demand model which seeks to represent and then manipulate overall electricity demand under different scenarios needs to take account of the timing of people's activities. Representations of the time and timing of activities play a vital role in describing the timing of demand and its consequences for time-related scenarios, such as future electric vehicle charging schedules. Understanding where routines are most strongly embedded in everyday lives may provide crucial insights into the predictability of activities and their associated loads.

Whilst this research can only contribute a partial insight into the flexibility of activities at the time of peak demand, other results suggest that working with averages or household types may be insufficient. For example, according to the UK Government, modelling to predict households' electricity consumption based on property, household income and tenure have so far been able to explain less than $40 \%$ of the variation ${ }^{54}$. Any intervention, through price, technology or control needs to take into account what people do in relation to peak demand. In order for demand side response to penetrate the residential market and provide innovative ways of balancing supply and demand, any intervention on load shifting needs to be informed not only by aggregate load profiles, but also by patterns of activities.

\section{Acknowledgements}

This work was supported by the Engineering and Physical Sciences Research Council [grant number EP/K011723/1] as part of the RCUK Energy Programme and by EDF as part of the R\&D ECLEER Programme. The following individuals contributed to part of the analysis in this paper: $\mathrm{Dr}$ 
Corelia Baibarac and Dr Giulio Mattioli. The authors thank anonymous reviewers and the Journal editors for their useful comments.

\section{Authors' contribution}

Jacopo Torriti and Richard Hanna wrote the main theoretical, methodological and findings sections of the manuscript. Godwin Yeboah contributed to GPS analysis; Ben Anderson contributed to time use analysis; and Angela Druckman contributed to GHG analysis.

\section{Declaration of conflicting interests}

The authors declare that there is no conflict of interest.

\section{References}

1. Geller $\mathrm{H}$, Harrington $\mathrm{P}$, Rosenfeld $\mathrm{AH}$, et al. Policies for increasing energy efficiency: Thirty years of experience in OECD countries. Energy Policy 2006; 34(5): 556-573.

2. Strbac G, Gan CK, Aunedi M, et al. Benefits of advanced smart metering for demand response based control of distribution networks. Summary report. Imperial College and Energy Networks Association (ENA), 2010.

3. Warren P. A review of demand-side management policy in the UK. Renewable Sustainable Energy Rev 2014; 29: 941-951.

4. Torriti J and Grünewald P. Demand side response: Patterns in Europe and future policy perspectives under capacity mechanisms. Economics of Energy \& Environmental Policy 2014; 3, 32-46.

5. Strengers Y. Peak electricity demand and social practice theories: Reframing the role of change agents in the energy sector. Energy Policy 2012; 44(0): 226-234.

6. Southerton D. Habits, routines and temporalities of consumption: From individual behaviours to the reproduction of everyday practices. Time and Society 2012; 22(3): 335-355.

7. Shove E. Beyond the ABC: climate change policy and theories of social change. Environment and Planning A 2010; 42(6): 1273.

8. Abrahamse $W$, Steg $L$, Vlek $C$, et al. A review of intervention studies aimed at household energy conservation. Journal of Environmental Psychology 2005; 25(3): 273-291.

9. Heberlein TA and Warriner, GK. The influence of price and attitude on shifting residential electricity consumption from on to off-peak periods. J Econ Psychol 1983; 4:107-130.

10. Eibl-Eibesfeldt I. Ethology: The biology of behavior. Texas, USA: Holt, Rinehart and Winston, 1970.

11. Anable J, Anderson B, Shove E, et al. Categories, concepts and units: Representing energy demand in and through time. Working Paper 3, Lancaster: DEMAND Centre, http://www.demand.ac.uk/29/07/2014/wp-3-categories-concepts-and-units/ (2014, accessed 25 May 2015).

12. Walker G. The dynamics of energy demand: Change, rhythm and synchronicity. Energy Res Social Sci 2014; 1: 49-55. 
13. Lutzenhiser, L. 1993. Beyond price and attitude: Energy use as a social process. Annual Review of Energy and the Environment, 18, 259-263.

14. Shipworth D. The vernacular architecture of household energy models. Perspectives on Science 2013; 21(2): 250-266.

15. Swan LG and Ugursal VI. Modeling of end-use energy consumption in the residential sector: A review of modeling techniques. Renewable Sustainable Energy Rev 2009; 13(8): 1819-1835.

16. Suganthi $L$ and Samuel AA. Energy models for demand forecasting-A review. Renewable Sustainable Energy Rev 2011; 16: 1223-1240.

17. Jenkins SP and O'Leary NC. Gender differentials in domestic work, market work, and total work time: UK time budget survey evidence for 1974/5 and 1987. Scottish Journal of Political Economy 1997; 44(2): 153-164.

18. Southerton D. Squeezing time: Allocating practices, coordinating networks and scheduling society. Time \& Society 2003; 12(1), 5-25.

19. De Jong, R., \& Mensonides, W. (2003). Wearable GPS device as a data collection method for travel research. Institute of Transport Studies Working Paper, (ITS-WP-03-02).

20. Ipsos-RSL and Office for National Statistics. United Kingdom Time Use Survey.3rd Edition. Colchester, Essex: UK Data Archive, http://dx.doi.org/10.5255/UKDA-SN-4504-1 (2000, accessed 25 May 2015).

21. Office for National Statistics. ONS Omnibus Survey, Time Use Module, February, June, September and November 2005. Colchester, Essex: UK Data Archive, http://dx.doi.org/10.5255/UKDA-SN-5592-1 (2005, accessed 25 May 2015).

22. Clarkberg $M$ and Moen P. Understanding the Time-Squeeze Married Couples' Preferred and Actual Work-Hour Strategies. American Behavioral Scientist 2001; 44(7): 1115-1136.

23. Southerton $D$ and Tomlinson M. Pressed for time - the differential impacts of a 'time squeeze'. The Sociological Review 2005; 53(2): 215-239.

24. Ricotta C. Bridging the gap between ecological diversity indices and measures of biodiversity with Shannon's entropy: comment to Izsák and Papp. Ecol Modell 2002; 152(1): 1-3.

25. Vrotsou K and Forsell C. (2011). A qualitative study of similarity measures in event-based data. In: Smith MJ and Salvendy G (eds) Human interface and the management of information. Interacting with information. Springer: Berlin Heidelberg, 2011, pp. 170-179.

26. Ellegård $\mathrm{K} \&$ Palm J. Are you an individual or a household? Consequences for energy policy from concept confusion. Paper for BEHAVE Energy Conference 2014, Said Business School, University of Oxford.

27. Torriti J. A review of time use models of residential electricity demand. Renewable Sustainable Energy Rev 2014; 37: 265-272.

28. Neutens T, Schwanen T, \& Witlox F. The prism of everyday life: towards a new research agenda for time geography. Transport reviews, 2011; 31(1): 25-47.

29. Ellegård K. A time-geographical approach to the study of everyday life of individuals - A challenge of complexity. GeoJournal 1999; 48(3): 167-175.

30. Dill J, \& Gliebe J. Understanding and measuring bicycling behavior: a focus on travel time and route choice (Final report). Portland: Oregon Transportation Research and Education Consortium (OTREC), http://pdxscholar.library.pdx.edu/cgi/viewcontent.cgi?article=1027\&context=usp fac (2008; accessed 25 May 2015).

31. Yeboah G, Alvanides $S$ and Thompson EM. Everyday cycling in urban environments: Understanding behaviours and constraints in space-time. In: Helbich M, Arsanjani JJ, Leitnez 
$M$ (eds) Computational approaches for urban environments, geotechnologies and the environment series. New York: Springer Press, 2015, pp. 185-210.

32. Anderson T, Abeywardana V, Wolf J et al. (2010) National travel survey GPS feasibility study final report. London: NatCen \& GeoStats for Department for Transport, http://webarchive.nationalarchives.gov.uk/+/http://www.dft.gov.uk/pgr/statistics/datatables publications/personal/methodology/ntsreports/ntsgpsstudy.pdf (2010, accessed 25 May 2015).

33. Richardson IW, Thomson AM, Infield D, et al. Domestic energy use: A high-resolution energy demand model. Energy Build 2010; 42: 1878-1887.

34. Wilke U, Haldi F, Scartezzini JL, et al. A bottom-up stochastic model to predict building occupants' time-dependent activities. Build Environ 2012; 60: 254-264.

35. Richardson I, Thomson M and Infield D. A high-resolution domestic building occupancy model for energy demand simulations. Energy Build 2008; 40(8): 1560-1566.

36. López-Rodríguez MA, Santiago I, Trillo-Montero D, et al. Analysis and modeling of active home occupancy of the residential sector in Spain: an indicator of residential electricity consumption. Energy Policy 2013; 62: 742-751.

37. Druckman A, Buck I, Hayward B, et al. Time, gender and carbon: A study of the carbon implications of British adults' use of time. Ecol Econ 2012; 84: 153-163.

38. Costanza R. Embodied energy and economic valuation. Science 1980; 210(4475): 1219-1224.

39. Office for National Statistics. Environmental accounts, http://www. statistics.gov.uk/statbase/explorer.asp?CTG=3\&SL=\&D=4261\&DCT=32\&DT= 32\#4261 (2008, accessed 7 November 2008)

40. Department of Trade and Industry Digest of United Kingdom Energy Statistics (DUKES). London: The Stationery Office, 2006.

41. Department of Energy and Climate Change. Energy consumption in the UK, http://www.decc.gov.uk/en/content/cms/statistics/publications/ecuk/ecuk.aspx (2009, accessed 11 March 2010).

42. Parikh JK. Gender issues in energy policy. Energy Policy 1995; 23(9): 745-754.

43. Jacobsen GD, Kotchen MJ and Vandenbergh MP. The behavioral response to voluntary provision of an environmental public good: Evidence from residential energy demand. European Economic Review 2012; 56(5): 946-960.

44. Palmborg C. Social habits and energy consumption in single-family homes. Energy 1986; 11(7): 643-650.

45. Halvorsen B and Larsen, BM. The flexibility of household energy demand over time. Resource and Energy Economics 2001; 23(1): 1-18.

46. Miranda, V. Cooking, caring and volunteering: unpaid work around the world. OECD social, employment and migration working papers no. 116. Paris: Organisation for Economic Cooperation and Development, 2011.

47. Druckman A and Jackson T. The carbon footprint of UK households 1990-2004: a socioeconomically disaggregated, quasi-multiregional input-output model. Ecol Econ 2009; 68 (7): 2066-2077.

48. Raty, R. and Carlsson-Kanyama, A. (2009). Energy consumption by gender in some European countries. Energy Policy 38 (2010) 646-649.

49. Office for National Statistics. UK Environmental accounts, http://www.ons.gov.uk/ons/dcp171776 365592.pdf (2014, accessed 25 May 2015). 
50. Torriti J. Price-based demand side management: Assessing the impacts of time-of-use tariffs on residential electricity demand and peak shifting in Northern Italy. Energy 2012; 44 (1): 576583.

51. Bonke J. Paid work and unpaid work: Diary information versus questionnaire information. Social Indicators Research 2005; 70 (3): 349-368.

52. Kan M and Pudney S. Measurement error in stylised and diary data on time use, ISER Working Paper 2007-03. Colchester: University of Essex.

53. Anderson, B. Small area estimation as a tool for thinking about spatial variation in energy demand. Paper presented at: Spatial variation in energy use, attitudes and behaviours: Implications for smart grids and energy demand. London: Policy Studies Institute, http://www.psi.org.uk/site/news article/1734 (2014, accessed 26 May 2015).

54. DECC. United Kingdom housing energy fact file. London: Department of Energy and Climate Change, 2013. 